\title{
Space-time dynamics of carbon and environmental parameters related to carbon dioxide emissions in the Buor-Khaya Bay and adjacent part of the Laptev Sea
}

\author{
I. P. Semiletov ${ }^{1,2}$, N. E. Shakhova ${ }^{1,2}$, I. I. Pipko ${ }^{2}$, S. P. Pugach ${ }^{2}$, A. N. Charkin ${ }^{2}$, O. V. Dudarev ${ }^{2}$, D. A. Kosmach ${ }^{2}$, and \\ S. Nishino ${ }^{3}$ \\ ${ }^{1}$ International Arctic Research Center, University of Alaska Fairbanks, Fairbanks, AK, USA \\ ${ }^{2}$ V.I. Il'ichev Pacific Oceanological Institute, Far Eastern Branch of the Russian Academy of Science, Vladivostok, Russia \\ ${ }^{3}$ Research Institute for Global Change, Japan Agency for Marine-Earth Science and Technology, Yokosuka, Japan \\ Correspondence to: I. P. Semiletov (igorsm@iarc.uaf.edu)
}

Received: 28 December 2012 - Published in Biogeosciences Discuss.: 6 February 2013

Revised: 11 June 2013 - Accepted: 27 July 2013 - Published: 11 September 2013

\begin{abstract}
This study aims to improve understanding of carbon cycling in the Buor-Khaya Bay (BKB) and adjacent part of the Laptev Sea by studying the inter-annual, seasonal, and meso-scale variability of carbon and related hydrological and biogeochemical parameters in the water, as well as factors controlling carbon dioxide $\left(\mathrm{CO}_{2}\right)$ emission. Here we present data sets obtained on summer cruises and winter expeditions during $12 \mathrm{yr}$ of investigation. Based on data analysis, we suggest that in the heterotrophic BKB area, input of terrestrially borne organic carbon (OC) varies seasonally and inter-annually and is largely determined by rates of coastal erosion and river discharge. Two different BKB sedimentation regimes were revealed: Type 1 (erosion accumulation) and Type 2 (accumulation). A Type 1 sedimentation regime occurs more often and is believed to be the quantitatively most important mechanism for suspended particular matter (SPM) and particulate organic carbon (POC) delivery to the $\mathrm{BKB}$. The mean SPM concentration observed in the BKB under a Type 1 regime was one order of magnitude greater than the mean concentration of SPM $\left(\sim 20 \mathrm{mg} \mathrm{L}^{-1}\right)$ observed along the Lena River stream in summer 2003. Loadings of the $\mathrm{BKB}$ water column with particulate material vary by more than a factor of two between the two regimes. Higher partial pressure of $\mathrm{CO}_{2}\left(p \mathrm{CO}_{2}\right)$, higher concentrations of nutrients, and lower levels of oxygen saturation were observed in the bottom water near the eroded coasts, implying that coastal erosion and subsequent oxidation of eroded organic matter $(\mathrm{OM})$ rather than the Lena River serves as the
\end{abstract}

predominant source of nutrients to the BKB. Atmospheric $\mathrm{CO}_{2}$ fluxes from the sea surface in the BKB vary from 1 to $95 \mathrm{mmol} \mathrm{m}^{-2}$ day $^{-1}$ and are determined by specific features of hydrology and wind conditions, which change spatially, seasonally, and inter-annually. Mean values of $\mathrm{CO}_{2}$ emission from the shallow Laptev Sea were similar in September 1999 and $2005\left(7.2\right.$ and $7.8 \mathrm{mmol} \mathrm{m}^{-2}$ day $^{-1}$, respectively), while the $\mathrm{CO}_{2}$ efflux can be one order lower after a strong storm such as in September 2011. Atmospheric $\mathrm{CO}_{2}$ emissions from a thawed coastal ice complex in the BKB area varied from 9 to $439 \mathrm{mmol} \mathrm{m}^{-2} \mathrm{day}^{-1}$, with the mean value ranged from 75.7 to $101 \mathrm{mmol} \mathrm{m}^{-2}$ day $^{-1}$ in two years (September 2006 and 2009), suggesting that at the time of observations the eroded coastal area served as a more significant source of $\mathrm{CO}_{2}$ to the atmosphere than the tundra (mean value: $22.7 \mathrm{mmol} \mathrm{m}^{-2} \mathrm{day}^{-1}$ ) on the neighboring Primorsky coastal plain (September 2006). The observed increase in the Lena River discharge since the 1990s suggests that increased levels of "satellite-derived" annual primary production could be explained by an increasing load of humic acids delivered to shelf water; in this water the color resulting from the presence of CDOM (colored dissolved organic matter) mimics the color resulting from the presence of $\mathrm{Chl} a$ when seen from space. Because the BKB area can be employed as an integrator of ongoing changes in the surrounding environment, we suggest that under ongoing changes, more nutrients, products of eroded OC transformation and river transport, will be delivered to the Arctic Ocean with its shrinking ice cover, 
potentially increasing primary production outside of the shallow East Siberian Arctic Shelf (ESAS). At the same time, because the ESAS is characterized by very low transparency which limits euphotic layer thickness, excessive $p \mathrm{CO}_{2}$ will not be utilized by photosynthesis but will rather be emitted to the atmosphere at increasing rates, affecting regional $\mathrm{CO}_{2}$ balance.

\section{Introduction}

Unlike other oceans, the Arctic Ocean is completely surrounded by permafrost, which is being degraded at an increasing rate under conditions of warming which are most pronounced in Siberia and Alaska (ACIA, 2004; AMAP: SWIPA, 2012). Permafrost underlies a substantial fraction of the Arctic; its thawing accelerates river discharge and carbon losses from soils (Savelieva et al., 2000; Freeman et al., 2001). Thaw and release of organic carbon (OC) from Arctic permafrost is postulated to be one of the most powerful mechanisms causing a net redistribution of carbon from land and ocean to the atmosphere (Gruber et al., 2004; Goñi et al., 2005; IPCC, 2007; Canadell and Raupach, 2009). Because more than $30 \%$ of the planet's OC storage is in the Arctic region (Tarnocai et al., 2009), remobilization of this carbon and its involvement in the modern biogeochemical cycle was suggested to contribute to the carbon dioxide $\left(\mathrm{CO}_{2}\right)$ and methane $\left(\mathrm{CH}_{4}\right)$ atmospheric maxima observed above the Arctic (IPCC, 2007; Semiletov et al., 1996a, b; Shakhova et al., 2010a, b, c; Zimov et al., 1993, 1997). A recent assessment of the carbon balance of Arctic tundra (and boreal forests) shows that Arctic tundra serves as a sink for atmospheric $\mathrm{CO}_{2}$ (McGuire et al., 2012), while the East Siberian Arctic Shelf (ESAS) was shown to be a source of $\mathrm{CO}_{2}$ (Semiletov et al., 2007; Semiletov and Pipko, 2007; Pipko et al., 2005, 2008, 2011a). Nevertheless, many gaps still exist in our understanding of the processes responsible for OC transport, transformation, and fate in the Arctic shelf water.

The ESAS is a very important part of the Arctic shelf. The ESAS makes up a significant fraction $(\sim 25 \%)$ of the shelf and holds $>80 \%$ of the Arctic shelf sub-sea permafrost and permafrost-related unique Arctic shelf hydrates (Soloviev, 1987; ACIA, 2004; Shakhova et al., 2010a). It accepts about $30 \%$ of Arctic river discharge, and is surrounded by a coastline that exhibits the highest rates of coastal erosion in the world (Rachold et al., 2004; Grigoriev et al., 2006; Semiletov et al., 2011, 2012; Vonk et al., 2012). The ESAS not only responds to the ongoing Arctic warming, but also accommodates the signal of the terrestrial ecosystems' response which is delivered to the ESAS by Arctic rivers (Guo et al., 2004; Porcelli et al., 2009; Gustafsson et al., 2011; Semiletov et al., 2011; Proshutinsky et al., 2012; Feng et al., 2013). The coastal zone of the ESAS plays the most important role in this response, because incoming river-borne signals and in situ marine signals first interact in this zone. Processes that develop here include carbon transport, accumulation, and transformation, and seaward export of particulate and dissolved materials to offshore shelf/slope regions (Dudarev et al., 2003, 2006; van Dongen et al., 2008; Cooke et al., 2009; Alling et al., 2010; Pipko et al., 2011b; Sánchez-Garcia et al., 2011; Semiletov et al., 2012; Vetrov et al., 2008; Vonk et al., 2012; Feng et al., 2013). In addition, the warming effect of river runoff on the underlying sub-sea permafrost also begins in the coastal zone (Shakhova et al., 2009a, b; Semiletov et al., 2011; Nicolsky and Shakhova, 2010; Nicolsky et al., 2012). Recently reported warming of the shelf water by up to $3{ }^{\circ} \mathrm{C}$ and input of riverine waters can accelerate warming of the sub-sea permafrost, causing unsealing of seabed OC and $\mathrm{CH}_{4}$ deposits (Holemann et al., 2011; Shakhova and Semiletov, 2007, 2012).

It has been suggested that carbon cycling in the ESAS is determined by unequal contributions of river discharge and coastal erosion, which supply the shelf water with large amounts of terrestrial OC in both particulate and dissolved forms (Gordeev, 1996; Lara et al., 1998; Boucsein et al., 2000; Rachold et al., 2000; Stein and Macdonald, 2004; Macdonald et al., 2008; Pipko et al., 2010; Semiletov et al., 2011). Further transformation of terrestrial organic matter (OM), much poorer in nutrients than marine $\mathrm{OM}$, creates a unique aqueous distribution pattern of biogeochemical parameters and nutrients in the sea water. Analysis of biogeochemical parameters indicative of degradation showed that terrestrial OC was substantially older but less degraded in the surface sediments than in the surface water (Vonk et al., 2010). It has been shown that transformation of coastal erosion-induced OM starts well before it reaches the shelf water (Dudarev et al., 2003). The result of such transformation is the failure of $>50 \%$ of mobilized OC to reach the shelf water due to its release to the atmosphere as $\mathrm{CO}_{2}$ (Vonk et al., 2012).

The fate of particulate OC (POC) was poorly understood until recently, when it was shown that POC is biologically degradable to a very high degree. Its transformation in shelf water sooner rather than later results in the high partial pressure of $\mathrm{CO}_{2}\left(p \mathrm{CO}_{2}\right)$ observed in the water (Semiletov, 1999a,b; Semiletov et al., 2007, 2011, 2012; Pipko et al., 2005, 2008, 2011a; Anderson et al., 2009, 2011). Dissolved OC (DOC) is believed to be brought mainly by rivers and to be a relatively inert carbon stock in the near-shore zone, because its pool turnover time is significantly greater than the shelf water residence time (Dittmar and Kattner, 2003; Alling et al., 2010).

From this point of view, the Buor-Khaya Bay (BKB) in the southeastern Laptev Sea is a key site where all these processes interact, determining specific dynamic patterns of hydrological, biogeochemical, and sedimentological parameters observed in the water and water-air interface year-round. Our current contribution aims to share with readers our improved understanding of both OC cycling in this unique area and the factors controlling $\mathrm{CO}_{2}$ emission - understanding 
gained through 12 years of studying the inter-annual, seasonal, and meso-scale variability of carbon stocks and related hydrological and biogeochemical parameters in the BKB area and adjacent part of the Laptev Sea.

\section{Data sets and methods}

\subsection{Study area}

The BKB is located in the southeastern Laptev Sea and is one of the most important Laptev Sea gulfs. It is located between the Lena Delta to the west and Cape Buor-Khaya to the northeast (Fig. 1). The total area of the BKB is about $30000 \mathrm{~km}^{2}$; water depth varies mostly from 10 to $20 \mathrm{~m}$.

The BKB is the primary recipient of Lena River discharge; it receives about $80-90 \%$ of the river's water and up to $85 \%$ of its sediment discharge (Kassens et al., 1999; Dudarev et al., 2006). The BKB is a hotspot for erosion input from coastal ice complexes (called "yedoma" by local people) and was reported to be an important region for land-seaatmosphere carbon exchanges (Semiletov, 1999a, b; Charkin et al., 2011; Karlsson et al., 2011; Semiletov et al., 2011). Erosion input stems from rapidly collapsing ice complexes, which compose up to $30 \%$ of the BKB coastline. Rates of coastal retreat as high as $2-3 \mathrm{~m} \mathrm{yr}^{-1}$ were reported within the Lena River delta (Grigoriev, 1993, 2008), while at some places, e.g. on Muostakh Island, which is located roughly in the middle of the gulf, loss by erosion can average $11 \mathrm{~m} \mathrm{yr}^{-1}$ (Grigoriev and Kunitsky, 2000; Fig. 2).

Hence, the BKB's sedimentary and terrestrial OC material input stems from two major sources: fluvial sediment discharge from the Lena River, and thermal collapse and erosion input from coastal and deltaic ice complexes (Karlsson et al., 2011). Hydro-meteorological conditions, Lena River discharge, and rates of coastal erosion vary inter-annually, creating different backgrounds for the sedimentation processes and OC transport and distribution in the water column and in the surface sediments (Savelieva et al., 2000; Semiletov et al., 2000, 2011; Charkin et al., 2011).

\subsection{Materials and methods}

Hydrographic observations and sampling were carried out in the southeastern Laptev Sea during the fall seasons of 19992000, 2004-2006, 2008-2009, and 2011, and winter seasons of 2002 and 2007 (Table 1).

\subsection{1 pH}

Seawater samples were collected in Niskin bottles and then transferred into smaller bottles for chemical analysis. $\mathrm{pH}$ was determined potentiometrically and reported on the total hydrogen ion concentration scale (DOE, 1994). pH measurement precision was about $\pm 0.004 \mathrm{pH}$ units. Direct comparison between potentiometric and spectrophotometric $\mathrm{pH}$
Table 1. List of summer cruises and winter expeditions (19992011).

\begin{tabular}{ll}
\hline Cruise & Date \\
\hline Dunay 1999 & 09 September to 24 September \\
Nikolay Kolomeitsev 2000 & 30 August to 5 September \\
Winter surveys 2002 & 15 April to 4 May \\
Ivan Kireev 2004 & 24 August to 1 September \\
& 14 September \\
Neptun 2005 & 3 September to 8 September \\
Auga 2005 & 21 September to 25 September \\
Neptun 2006 & 5 September to 27 September \\
Winter surveys 2007 & 3 April to 13 April \\
Yakob Smirnitskiy 2008 & 23 August to 29 August \\
& 16 September to 18 September \\
TB-0012 2008 & 14 August to 26 August \\
TB-0012 2009 & 25 August to 07 September \\
TB-0012 2010 & 24 August to 28 August \\
Academic M.A. & 18 September to 30 September \\
Lavrentiev 2011 & \\
\hline
\end{tabular}

measurements (both on the "total" scale) was carried out in September 2008. Results of this comparison demonstrate good concurrence between the two methods (Pipko et al., 2011a). In 2008 the $\mathrm{CO}_{2}$ system was studied by measuring concentrations of total dissolved inorganic carbon $\left(C_{\mathrm{T}}\right)$, total alkalinity $\left(A_{\mathrm{T}}\right)$, and $\mathrm{pH}$, and computations using the different constituents showed good $\mathrm{pH}$ accuracy; $C_{\mathrm{T}}$ and $A_{\mathrm{T}}$ were calibrated versus certified reference materials (CRMs) supplied by Andrew Dickson, Scripps Institution of Oceanography.

\subsubsection{Total alkalinity}

In August-September 2004 and 2005 and in winter 2002 and $2007 A_{\mathrm{T}}$ was determined as proposed in DOE (1994). The $A_{\mathrm{T}}$ samples were poisoned with a mercuric chloride solution at the time of sampling. Samples were kept in the dark and were analyzed in the lab within one month using an indicator titration method in which $25 \mathrm{~mL}$ of seawater was titrated with $0.02 \mathrm{M}$ hydrochloric acid $(\mathrm{HCl})$ in an open cell according to Bruevich (1944). In 2000 the Carbon Dioxide in the Ocean working group of the North Pacific Marine Science Organization (PICES) performed an intercalibration of $A_{\mathrm{T}}$ in seawater using CRMs. The results of the intercalibration showed that the alkalinity values obtained by the Bruevich method are in agreement with the standard within $\pm 1 \mu \mathrm{mol} \mathrm{kg}{ }^{-1}$ when state-of-the-art analytical practice is applied (Pavlova et al., 2008).

In August-September $2008 A_{\mathrm{T}}$ was determined after $\mathrm{pH}$ from the same sample on board the "Yakob Smirnitskiy", using an open-cell potentiometric titration method; $0.05 \mathrm{M} \mathrm{HCl}$ was used and the endpoint was determined by a Gran function (Haraldsson et al., 1997). The concentrations thus obtained were calibrated against CRMs. In September $2011 A_{\mathrm{T}}$ 
a)

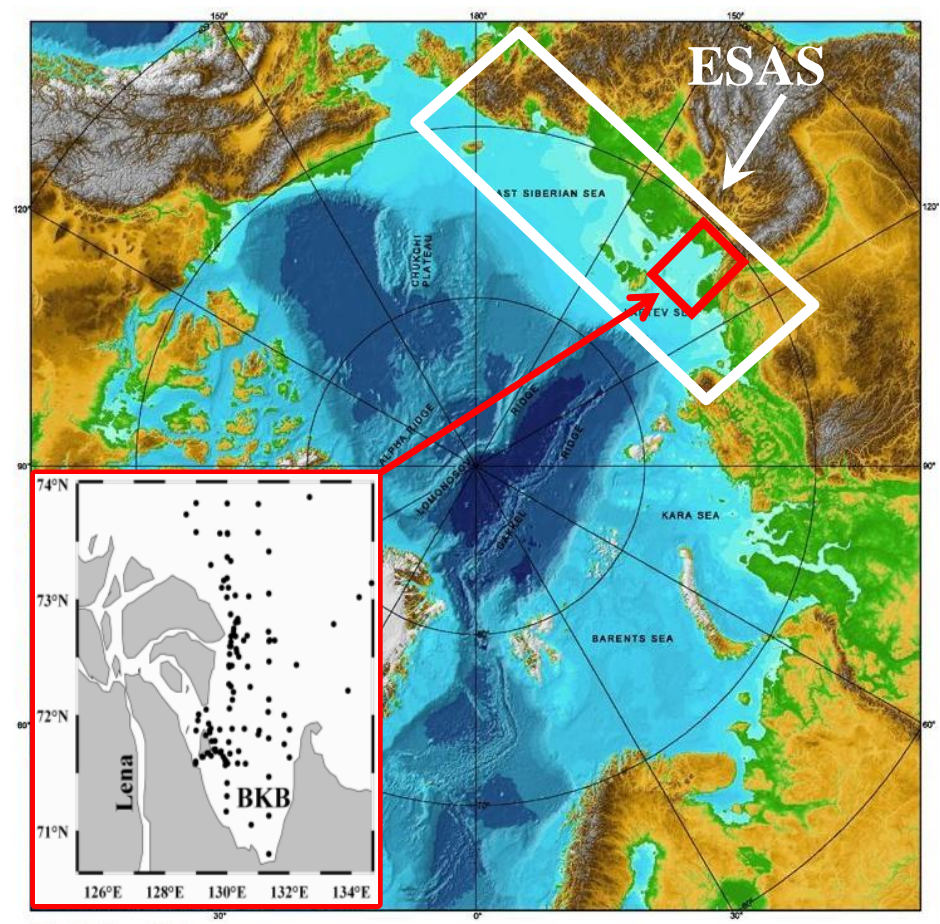

b)

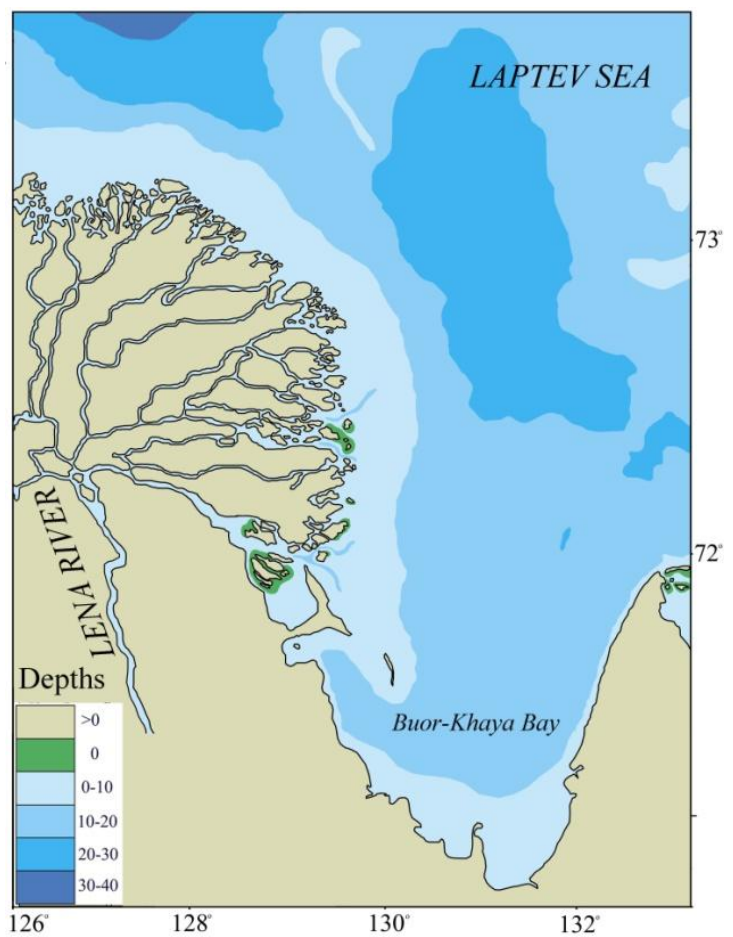

Fig. 1. (a) Study area: position of the Buor-Khaya Bay (BKB) of the Laptev Sea in the ESAS. Study area coverage with oceanological stations (black dots) is shown in the lower left corner (red rectangle); (b) bathymetry of the BKB area.

was determined onboard the "Academic M. A. Lavrentiev" according to Bruevich (1944), again using CRMs.

The precision of both titration methods was similar at about $0.1 \%$.

\subsubsection{Total dissolved inorganic carbon}

To measure $C_{\mathrm{T}}$ (fall seasons 1999, 2000) we used a TSVET530 or LKHM-80MD gas chromatograph (GC), with a Porapak T (1.5 m, 80-120 mesh) and a flame-ionization detector (FID) run isothermally at $30^{\circ} \mathrm{C}$ with hydrogen carrier gas; a stripping $\mathrm{GC}$ technique similar to that described in Weiss (1981) was used. The $C_{\mathrm{T}}$ calibrations were based on 0.73 , 1.02 , and $1.99 \mathrm{mM}$ standard solutions of sodium carbonate $\left(\mathrm{Na}_{2} \mathrm{CO}_{3}\right)$ that were prepared gravimetrically in fresh distilled water. Conversion of $\mathrm{CO}_{2}$ to $\mathrm{CH}_{4}$ after the Porapak column was done in a nickel (Ni)-catalyst column $(14 \mathrm{~cm}$ Chromaton, $80-100$ mesh, coated with $\mathrm{Ni}$ ) at $400^{\circ} \mathrm{C}$ (Semiletov, 1993). The measurements are reproducible to within $\pm 1-$ $2 \%$.

\subsubsection{Partial pressure of $\mathrm{CO}_{2}$}

The seawater $p \mathrm{CO}_{2}$ was computed from $\mathrm{pH}-A_{\mathrm{T}}$ using CO2SYS (Lewis and Wallace, 1998), except for cruises in 1999 and 2000 on which the $\mathrm{pH}-C_{\mathrm{T}}$ pair was used. The carbonic acid dissociation constants $\left(K_{1}\right.$ and $\left.K_{2}\right)$ of Mehrbach et al. (1973) as refit by Dickson and Millero (1987) were used. The uncertainty in computed $p \mathrm{CO}_{2}$ was about $\pm 10 \mu$ atm.

\subsubsection{Dissolved oxygen}

Dissolved oxygen $\left(\mathrm{O}_{2}\right)$ concentrations were obtained using a Winkler titration system, giving a precision of $\sim 3 \mu \mathrm{mol} \mathrm{kg}-1$ for 1999-2005 data and $\sim 1 \mu \mathrm{mol} \mathrm{kg}{ }^{-1}$ for 2008 and 2011 data. These values were then converted to percent saturation, following Weiss (1970).

\subsubsection{Nutrients}

Nitrates, silicates, and phosphates were determined by traditional oceanographic techniques prescribed by Holmes et al. (2001). In September 2008 they were determined by a SmartChem analyzer (Westco Scientific Instruments Inc.; http://www.westcoscientific.com/pages/smartchem200. htm\#applications). More detailed descriptions can be found elsewhere (Anderson et al., 2009, 2011). The samples were filtered before analysis and evaluated by a 6- to 8-point calibration curve at $\sim 1 \%$ precision. 
a)

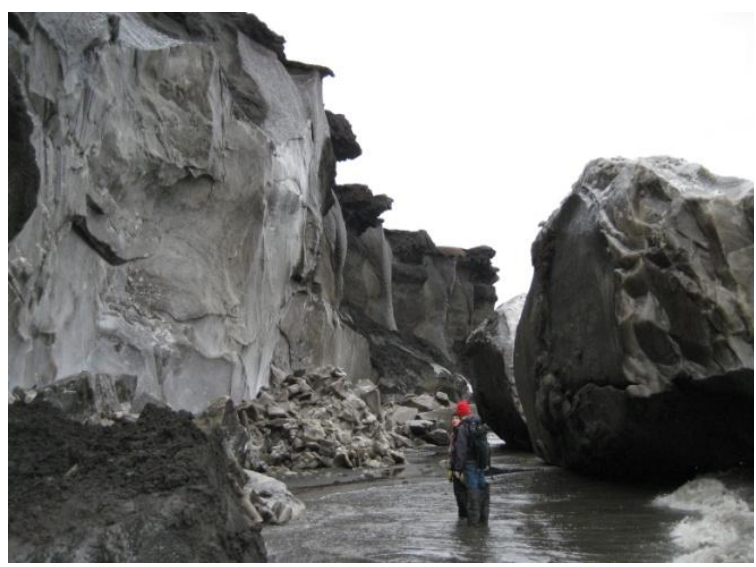

b)

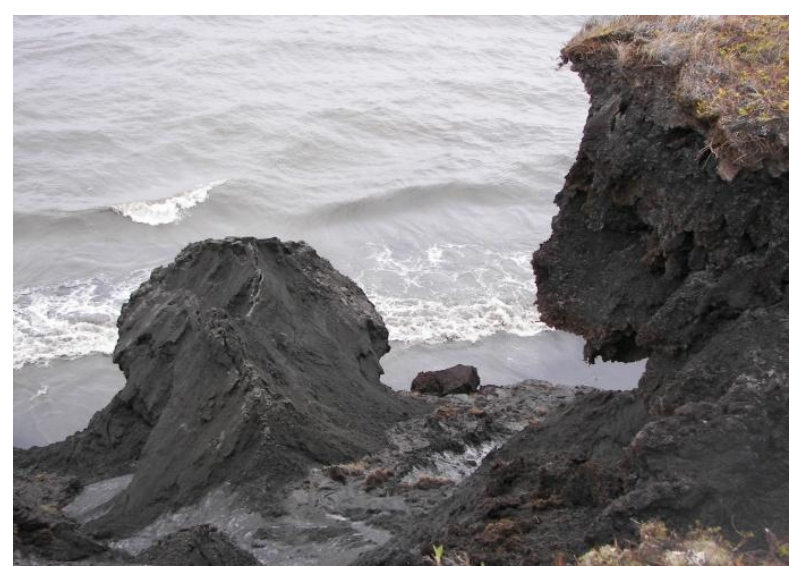

Fig. 2. Coastal erosion as seen on the northern cape of Muostakh Island (photos by I. P. Semiletov). During $<2$ weeks in early September 2006, the northern cape of Muostakh Island (Buor-Khaya Bay of the Laptev Sea) retreated $>20 \mathrm{~m}$, delivering a large amount of eroded organic matter to the sea: (a) and (b) represent different parts of the island.

\subsubsection{Dissolved organic carbon}

DOC samples were filtered immediately through glass fiber filters, preserved with $\mathrm{HCl}$ to $\mathrm{pH} \sim 2$, and stored in glass vials until analyses via high-temperature combustion using the Shimadzu TOC method (Alling et al., 2010).

\subsubsection{Hydrological parameters}

During the 2004-2011 cruises a Seabird SBE19plus Profiler (www.seabird.com) was used for measurements of conductivity, temperature, photosynthetically active radiation (PAR) (by LI-193SA Spherical Quantum Sensor), turbidity (by OBS-3 Sensor), and fluorescence. A WetStar fluorimeter was used to assess the in situ colored dissolved OM (CDOM) concentration; this instrument has a single excitation $\left(E_{\mathrm{x}}=370 \mathrm{~nm}\right) / \mathrm{emission}\left(E_{\mathrm{m}}=460 \mathrm{~nm}\right)$ wavelength pair. These measurements characterized the distribution of CDOM at $0.20 \mathrm{~m}$ vertical intervals at the oceanographic stations.

\subsubsection{Analytical methods for sedimentological research}

Size composition of fine-grained sediments $(<0.1 \mathrm{~mm})$, coarse-grained sediments $(>0.1 \mathrm{~mm})$, and suspended particulate matter (SPM) was studied using a laser microanalyzer (Analysette 22, Fritsch $\mathrm{GmbH}$ ). Sieve analysis was used to examine coarse sediments (Petelin, 1961). Bottom sediment sizing was then performed on the basis of a three-component classification system (Shepard, 1954) that defines sand (1$0.1 \mathrm{~mm})$, silt $(0.1-0.01 \mathrm{~mm})$, and clay $(<0.01 \mathrm{~mm})$.
The SPM content was obtained by filtration through membrane filters with pore diameter of $0.47 \mu \mathrm{m}$ followed by gravimetry. The POC composition was analyzed on samples filtered on pre-combusted $\left(12 \mathrm{~h}, 450^{\circ} \mathrm{C}\right)$ glass fiber filters (GF/Fs, $0.7 \mu \mathrm{m}$, Whatman), 47 or $142 \mathrm{~mm}$ in diameter; afterward filtration samples were immediately transferred to precombusted aluminum envelopes, frozen, and kept at $-18^{\circ} \mathrm{C}$ until analysis.

Surface sediment samples were retrieved with a Van Veen grab sampler. The top-most surface sediment layer $(0-5 \mathrm{~cm})$ was transferred with stainless steel spatulas to pre-cleaned polyethylene containers before being stored at $-18^{\circ} \mathrm{C}$ until analysis.

Elementary $\mathrm{OC}$ and isotopic $\left(\delta^{13} \mathrm{C}\right)$ composition of bottom sediment were determined by Carlo Erba elemental analyzers and a Finnigan MAT Delta Plus mass spectrometer, respectively, at the International Arctic Research Center, University of Alaska, Fairbanks (USA), and with similar instruments at Stockholm University (Sweden). Accuracy and reproducibility of the isotope results were $\pm 0.1 \%$ o. Freezedried sediments from each station were weighed into precombusted silver capsules $(5 \times 9 \mathrm{~mm}$, Säntis Analytical AG, Teufen, Switzerland), acidified in situ with $50 \mu \mathrm{L} 1 \mathrm{M} \mathrm{HCl}$ for removal of carbonates, and dried overnight at $60^{\circ} \mathrm{C}$ following a procedure adapted from Gustafsson et al. (1997). A similar procedure of in situ acidification and subsequent drying in silver capsules $(5 \times 12 \mathrm{~mm})$ was followed to measure POC on sub-sampled GF/F ( $8-12$ punches, $5 \mathrm{~mm}$ each). Acidified samples were analyzed in triplicate for OC content and $\delta^{13} \mathrm{C}$ composition using an isotope ratio mass spectrometer. 


\subsubsection{Air-sea $\mathrm{CO}_{2}$ fluxes}

On the 2004 and 2005 cruises atmospheric $\mathrm{CO}_{2}$ concentration was measured using the non-dispersive LI-820 infrared $\mathrm{CO}_{2}$ analyzer with accuracy better than $3 \%$ (www. licor.com); starting on the 2006 cruise the high-precision open-path LiCor-7500 was used (Semiletov et al., 2007). On the 1999 cruise atmospheric $\mathrm{CO}_{2}$ was not measured. Hence, to calculate the air-sea $\mathrm{CO}_{2}$ gradient we used the monthly mean latitude $\mathrm{CO}_{2}$ concentration (http://www.esrl.noaa.gov/ gmd/obop/brw/).

The equation published by Wanninkhof and McGillis (1999) was used to calculate the $\mathrm{CO}_{2}$ flux $\left(F_{\mathrm{CO}_{2}}\right)$ :

$F_{\mathrm{CO}_{2}}=K_{0} \cdot k \cdot\left(p \mathrm{CO}_{2}^{\mathrm{sw}}-p \mathrm{CO}_{2}^{\mathrm{air}}\right)$,

where $k=0.0283 \cdot u^{3} \cdot(660 / S c)^{0.5}$ and $K_{0}$ is the solubility of $\mathrm{CO}_{2}$ at the in situ temperature $\left(\mathrm{mol} \mathrm{m}^{-3} \mathrm{~atm}^{-1}\right), k$ is the gas transfer velocity $\left(\mathrm{cm} \mathrm{h}^{-1}\right), u$ is the wind speed $\left(\mathrm{m} \mathrm{s}^{-1}\right)$, and $S c$ is the Schmidt number for $\mathrm{CO}_{2}$ defined by Wanninkhof (1992). The wind speeds used in the calculation of transfer velocity were daily averaged values measured on board during each cruise. Air-sea fluxes were calculated at each hydrocast station. For calculating the integrated flux of the study area the station data were interpolated onto a uniform grid obtaining the area-weighted $\mathrm{CO}_{2}$ (and $\mathrm{CH}_{4}$ ) fluxes (Pipko et al., 2011a; Shakhova and Semiletov, 2007; Semiletov et al., 2007).

\subsubsection{1 $\mathrm{CO}_{2}$ out-gassing from the thawing ice complex}

The emission of $\mathrm{CO}_{2}$ from the thawing ice complex (IC) permafrost was measured simultaneously with the soil moisture content along the same transects in early September of 2009 (this study) and 2006 (Vonk et al., 2012). The measurements were taken along five aboveground transects crossing the northern part of Muostakh Island from west to east. The $\mathrm{CO}_{2}$ sampling transects roughly followed the soil sampling slopes, in order to assess potential emissions derived from the ice complex degradation suggested by the bulk and molecular analyses (Vonk et al., 2012). In situ $\mathrm{CO}_{2}$ analysis was carried out with two automatic lid chambers attached to an infrared gas analyzer (LICOR 8100), according to similar procedures detailed elsewhere (Semiletov et al., 2004). At the heart of the LI-8100 system lies the analyzer control unit, an O-ring sealed, weather-tight enclosure that houses system electronics and the infrared gas analyzer used to measure the change in $\mathrm{CO}_{2}$ and $\mathrm{H}_{2} \mathrm{O}$ concentrations in the soil chamber. The different mechanisms controlling the opening and closing of the chambers do not affect the measurements. Both chambers lower slowly onto the measurement site to minimize pressure pulsations that change soil $\mathrm{CO}_{2}$ concentrations. In total, $\mathrm{CO}_{2}$ emissions were measured in duplicate or triplicate ( 3 min per measurement) from each sampling site along the five transects. Although most of the $\mathrm{CO}_{2}$ sampling occurred on land, several $\mathrm{CO}_{2}$ measurements were collected at shallowly submerged sites along one transect, to check the $\mathrm{CO}_{2}$ out-gassing beyond the shoreline. Respiration fluxes are reported as $\mathrm{mmol} \mathrm{m}^{-2}$ day $^{-1}$ and represent average values of the duplicate or triplicate measurements.

\section{Results and discussion}

\subsection{Specific features of hydrology, sedimentation, and permafrost dynamics in the Buor-Khaya Bay}

Hydrological conditions in the BKB are determined by Lena River discharge changes, wind direction and speed, tidal fluctuations of the sea water level, and ice-related conditions. Climatic data show that riverine fresh waters propagate far to the east of the Lena River delta (Semiletov et al., 2005). Alteration of the salinity and temperature of the surface and the bottom shelf water layers depends on the river discharge (Fig. 3) and prevailing wind conditions (Proshutinsky and Johnson, 1997; Semiletov et al., 2000).

For example, in 2005 the annual Lena River discharge was low (about $617 \mathrm{~km}^{3}$ ) relative to three subsequent years (Fig. 3), and winds with average velocities of $11-12 \mathrm{~m} \mathrm{~s}^{-1}$ prevailed during our investigations. As a result, the water column in close proximity to the Lena Delta was mixed to the bottom, while most of the BKB was stratified (Fig. 4a and d). Salinity varied from 4.9 to 12.1 in the surface layer and from 8.9 to 31.5 in the bottom layer.

In summer 2005 observed temperatures varied from 3.5 to $5.5^{\circ} \mathrm{C}$ and from 0.9 to $5{ }^{\circ} \mathrm{C}$, respectively, in the surface and bottom layers (Fig. 5a and d). In winter 2007, surface and bottom layer salinities varied from 0.24 to 15.4 and from 0.7 to 27.4 , respectively (Fig. $4 \mathrm{~b}$ and e); temperatures ranged from -0.48 to $2.3^{\circ} \mathrm{C}$ in the surface layer and from -0.7 to $0.15^{\circ} \mathrm{C}$ in the bottom layer (Fig. $5 \mathrm{~b}$ and e). In contrast to summer 2005, in summer 2008 the Lena River discharge was very high $\left(716 \mathrm{~km}^{3}\right)$, while winds during the period of observations were mostly low $\left(1-2 \mathrm{~m} \mathrm{~s}^{-1}\right)$. This resulted in salinity variation from 0.1 to 8.4 in the surface layer and from 9.3 to 28.9 in the bottom layer (Fig. $4 \mathrm{c}$ and f). In summer 2008 temperature varied from 5.2 to $16.5^{\circ} \mathrm{C}$ in the surface water layer and from -1.37 to $7.5^{\circ} \mathrm{C}$ in the bottom water (Fig. $5 \mathrm{c}$ and $\mathrm{f}$ ).

Note that the annual Lena River discharge (http://rims.unh. edu/) observed in the decade of 1999-2008 varied between $457 \mathrm{~km}^{3}$ and $716 \mathrm{~km}^{3}$ (Fig. 3) and that mean annual discharge (MAD) for this period $\left(583 \mathrm{~km}^{3}\right)$ was $\sim 11 \%$ higher than MAD in the 1990s $\left(\sim 525 \mathrm{~km}^{3}\right)$. It has been suggested that this reflects a significant increase in the eastward zonal air water vapor transport from the North Atlantic to the Lena River watershed and increasing shelf-ward transport of permafrost thaw waters observed since the 1990s (Savelieva et al., 2000; Semiletov et al., 2000).

Two different BKB sedimentation regimes were revealed: Type 1 (erosion accumulation) and Type 2 (accumulation) (Charkin et al., 2011). Under Type 1 (2000-2006) erosion 


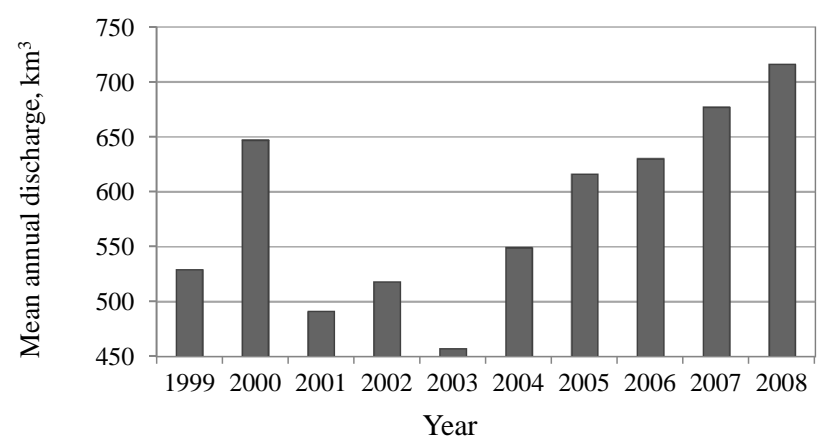

Fig. 3. Mean annual Lena River discharge (Kusur observation station) documented during the period of Buor-Khaya Bay observations.

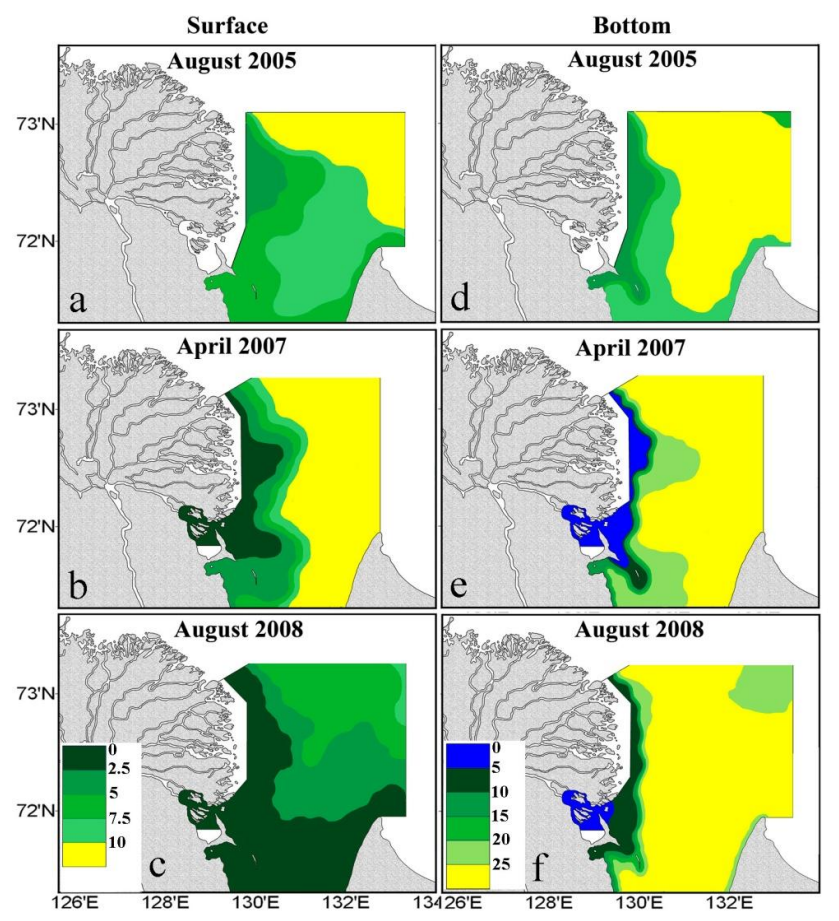

Fig. 4. Salinity of the surface and bottom Buor-Khaya Bay water layers. Salinity levels are shown as colored rectangles in (c) and (f).

accumulation conditions, terrigenous sources of SPM and POC stem predominantly from thermal erosion of coastal ice complexes, river discharge, and remobilized bottom sediments. A Type 1 sedimentation regime occurs more often and is believed to be the quantitatively most important mechanism for SPM and POC delivery to the BKB. According to our data, under a Type 1 regime concentrations of SPM in the near-bottom water layer can reach $187 \mathrm{mg} \mathrm{L}^{-1}$ (average $57.9 \mathrm{mg} \mathrm{L}^{-1}$ ) in the areas where river discharge dominates, and $594 \mathrm{mg} \mathrm{L}^{-1}$ in areas located close to the intensively degrading coast. A maximum POC content in surface waters exceeding $2.0 \mathrm{mg} \mathrm{L}^{-1}$ was also observed in the latter areas (Fig. 6a). Note that the mean SPM concentration
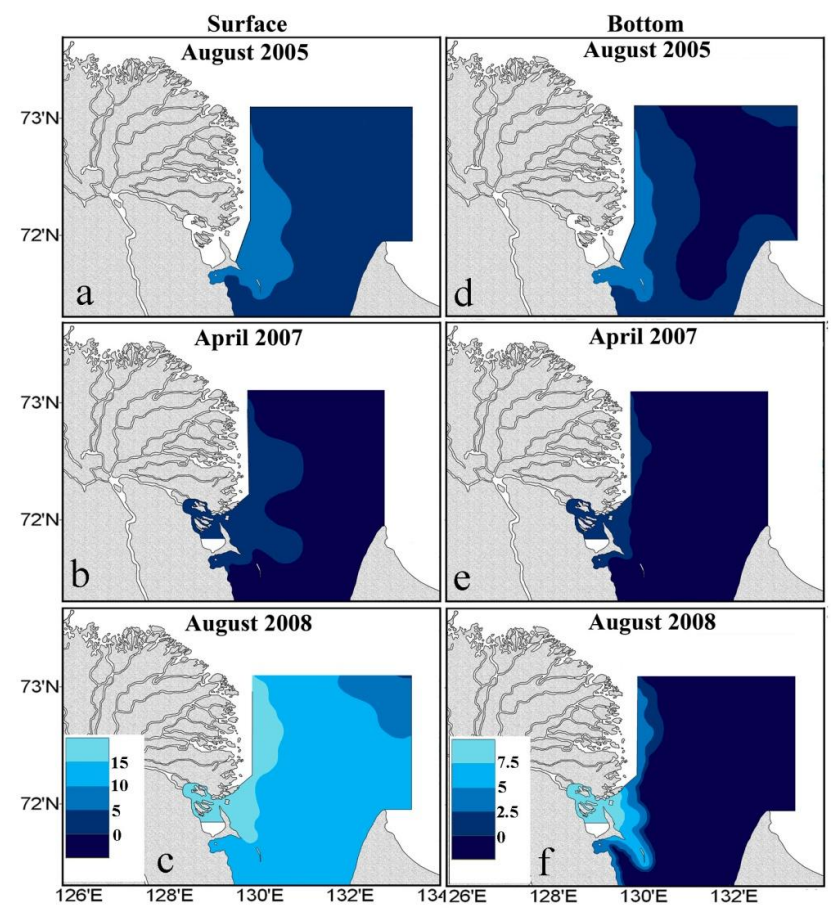

Fig. 5. Temperature of the surface and bottom BKB water layers in 2005, 2007, and 2008. Temperature levels $\left({ }^{\circ} \mathrm{C}\right)$ are shown as colored rectangles in (c) and (f).

observed in the BKB under a Type 1 regime was one order of magnitude greater than the mean concentration of SPM ( $\sim 20 \mathrm{mg} \mathrm{L}^{-1}$ ) observed along the Lena River stream in summer 2003 (Semiletov et al., 2011).

The Type 2 sedimentation regime usually occurs in winter but can be observed in summer under conditions of halted coastal erosion processes and low river flow or high river discharge associated with gentle winds. For example, in 2008, the year of high river discharge $\left(716 \mathrm{~km}^{3}\right)$ and halted erosion, SPM averaged $2.9 \mathrm{mg} \mathrm{L}^{-1}$ in the surface water and $4.8 \mathrm{mg} \mathrm{L}^{-1}$ in the bottom water in winter and $11.2 \mathrm{mg} \mathrm{L}^{-1}$ in the surface water and $13.4 \mathrm{mg} \mathrm{L}^{-1}$ in the bottom water in summer. The POC content did not exceed $0.1 \mathrm{mg} \mathrm{L}^{-1}$ in winter (Charkin et al., 2011) and $1.1 \mathrm{mg} \mathrm{L}^{-1}$ in summer (Fig. 6b). In Type 2 winter, combined terrigenous and marine-biogenic SPM and POC sources are dominating due to relatively low overall terrigenous input such as in April 2007 (Charkin et al., 2011). In Type 2 summer, river alluvium is also the major SPM and POC source (August 2008).

The water column SPM and POC loadings vary by more than a factor of two between the two regimes. Under the Type 1 sedimentation regime, the highest POC levels were confined to a north-south band east of the delta, in the prodelta, and around Muostakh Island, likely reflecting remobilization of OC from bottom sediments and input of OC from coastal ice complex retreat. Under the Type 2 sedimentation conditions, the highest POC levels were measured 
a)

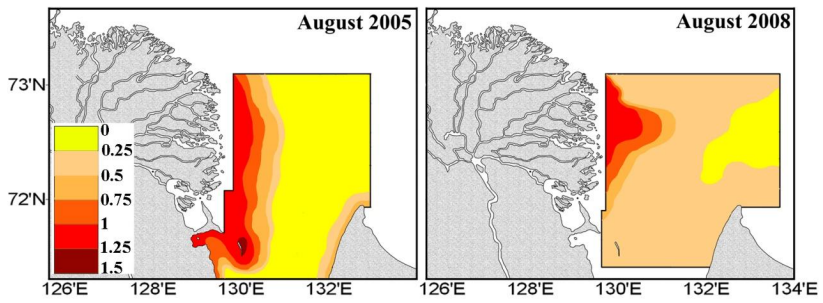

Fig. 6. Distribution of particular organic carbon in the Buor-Khaya Bay surface water layer in August 2005 (a) and August 2008 (b). Concentration range $\left(\mathrm{mg} \mathrm{L}^{-1}\right)$ is shown as colored rectangles in (a).

in an eastward direction, reflecting river plume propagation from the delta channels to the BKB interior (Charkin et al., 2011). The $\delta^{13} \mathrm{C}$ of sea water POC in 2005 ranged from -26.4 to $-28.5 \%$, typical values for both river-borne and coastal erosion-borne POC (Semiletov, 1999a,b; Kodina et al., 2001, 2002; Semiletov et al., 2012; Sánchez-Garcia et al., 2011; Vonk et al., 2010, 2012), while in $2008, \delta^{13} \mathrm{C}$ of POC varied from $-24.3 \%$ to $-32.2 \%$ (Fig. 7 ); this depletion reflects the strong terrestrial influence of the river plume extending eastward from the Lena Delta.

In winter (April) 2007, when river discharge was significantly smaller but propagated predominantly in the surface water layer, $\delta^{13} \mathrm{C}$ of surface water POC reflected the river contribution by exhibiting values as depleted as $-29.9 \%$; in the surface sediments the isotopic signature of old terrestrial carbon (from -24.9 to $-27.1 \%$ o) prevailed, with a small area of much heavier carbon (from -22.2 to $-24.0 \%$ o) that could be explained by a contribution from sea ice algae (Charkin et al., 2011).

\subsection{Biogeochemical signatures of organic matter degradation in sea water: dynamics of carbon, nutrients, and related environmental parameters}

Microbial degradation of OM that has been either produced photosynthetically in the euphotic zone or delivered by river and coastal erosion input occurs mostly at the pycnocline and the water-sediment interface, which results in decreasing $\mathrm{O}_{2}$ concentrations, increasing nutrients concentrations (primarily phosphate, $\mathrm{PO}_{4}^{3-}$, and nitrate, $\mathrm{NO}_{3}^{-}$), and increasing $p \mathrm{CO}_{2}$ in the bottom water. In the ESAS, the total amount of OC is the sum of primarily produced OC, OC delivered to the shelf water by river runoff, and OC resulting from coastal and bottom erosion (Stein and Macdonald, 2004; Semiletov et al., 2011, 2012). This pool consists of two major carbon stocks: POC and DOC. POC represents an earlier phase of OM transformation associated with poorly defined compositional changes such as aggregation/disaggregation of particles, incorporation of older and more degraded material, and recombination of organic compounds (Cooper et al., 2005). In the BKB, major POC sources include soil and yedoma-
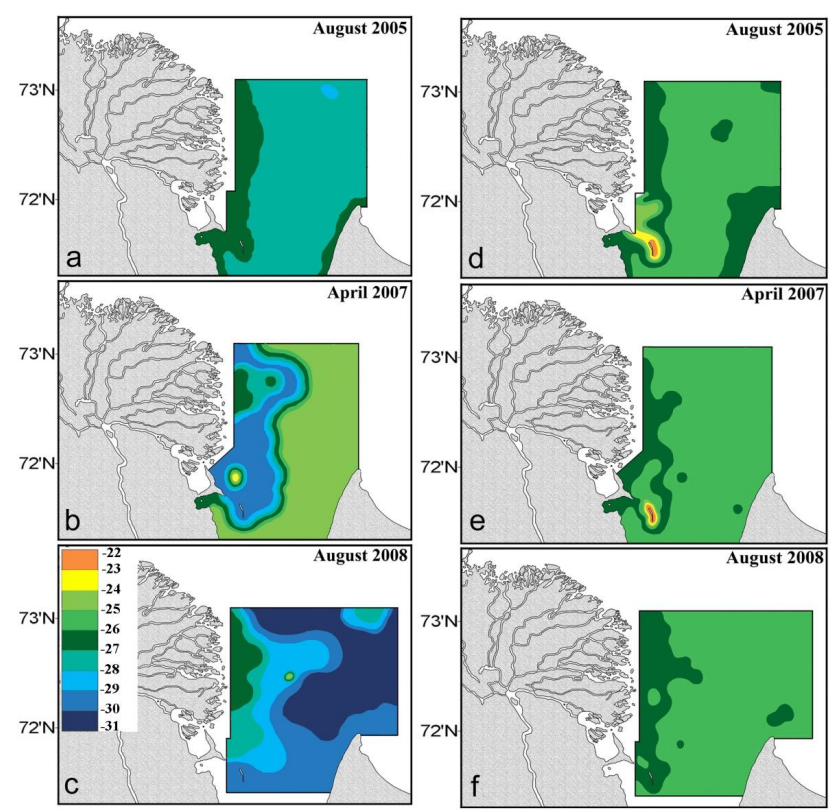

Fig. 7. Inter-annual variability of particular organic carbon $\delta 13 \mathrm{C}$ observed in the Buor-Khaya Bay sea water $(\mathbf{a}, \mathbf{b}, \mathbf{c})$ and surface sediments $(\mathbf{d}, \mathbf{e}, \mathbf{f})$. Observed value ranges $(\% o)$ are shown as colored rectangles in (c).

borne terrestrial $\mathrm{OC}$ and $\mathrm{OC}$ mobilized to the water column by coastal and bottom erosion (Vonk et al., 2010, 2012; Karlsson et al., 2011; Feng et al., 2013).

Riverine DOC inputs were long considered recalcitrant because of their high $C: N$ ratio $(\sim 50)$, the predominance of high molecular weight (HMW) compounds, and the relatively low degree of mixing observed in the estuaries (Mantoura and Woodward, 1983; Amon and Benner, 1996a, b). Nevertheless, it was shown that not all of the HMW DOC pool is refractory. To be incorporated into the microbial food web, large DOC molecules might be broken by sunlight into smaller and potentially more labile entities (Jørgensen et al., 1998; Wiegner and Seitzinger, 2001). About 17\% of the DOC was reported to be biologically available in lake, river, and marine ecosystems (Sondergaard and Middelboe, 1995). Recently, studies have shown that a significant fraction $(\sim 30 \%)$ of Arctic river DOC is degradable in the Arctic Ocean on a scale of 1-2 years (Alling et al., 2010; Holmes et al., 2008) - longer than the shallow shelf water residence time, which is on the order of several weeks (Nikiforov and Shpaikher, 1980; Semiletov et al., 2000). Thus, in the near-shore zone, riverine DOC can be considered a quasiconservative parameter.

Measurements of DOC are very labor-intensive and not always possible during cruises. At the same time, the fraction of dissolved organic matter (DOM) that is colored (CDOM) exhibits very strong positive correlation with fluorescence; it can easily be measured in situ using a WETStart fluorometer 
(Belzile et al., 2006). In the ESAS, CDOM is colored because riverine runoff is loaded with humic acids, which are representative of Arctic/sub-Arctic carbon cycling. Note that satellite data available for the ESAS often treat CDOM, incorrectly, as a fraction of ocean-color-derived $\mathrm{Chl} a$, resulting in an overestimation of primary production rates by an order of magnitude (Heim et al., 2013). In our previous studies, we found a strong positive correlation between river-borne DOC and CDOM (Semiletov et al., 2007; Shakhova et al., 2009b; Pugach and Pipko, 2013), which allowed us to further treat CDOM as a parameter indicative of riverine DOC.

We created three plots for 2005, 2008, and 2011, which show $C_{\mathrm{T}}$ vs. salinity (Fig. 8). The conservative mixing lines based on known $C_{\mathrm{T}}$ values for the Lena and Atlantic water are shown as dotted lines (between the green triangle and red rectangle) on each panel. Because we do not separate out dissolved inorganic carbon (DIC) data we used $C_{\mathrm{T}}$ data, which is the sum of DIC and particulate inorganic carbon (PIC), presumably represented by carbonate minerals. Our data show that the decay of eroded particulate $\mathrm{OM}$ and $\mathrm{OM}$ at the sediment surface results in low in situ $\mathrm{pH}$ values (as low as 7.24, total scale) and a naturally acidified marine environment (Semiletov et al., 2012, 2011). The southeast part of the Laptev Sea exhibits the lowest values of calcium carbonate saturation ever reported for the open marine environment: in the BKB area acidification lowers the saturation state of calcite and aragonite in the surface waters to 0.4 and 0.2 , and in the bottom water to 0.2 and 0.1 , respectively. Thus, because PIC contributes less than $2 \%$ to $C_{\mathrm{T}}$ in the study area, this parameter, in our opinion, gives a very good representation of DIC.

We suggest that the degradation of eroded POC from the coast (the main substrate for respiration in this system) is mainly responsible for the observed $C_{\mathrm{T}}$ surplus, which is better seen in the salinity range of 20-33.

Below we present more detailed analyses of the relationship between $\mathrm{CDOM}$, POC, water salinity, $p \mathrm{CO}_{2}$, and $\mathrm{NO}_{3}^{-}$ and $\mathrm{PO}_{4}^{3-}$ concentrations measured in the $\mathrm{BKB}$ water column in summer 2005 (Fig. 9) and 2011 (Fig. 10 and Fig. 11), and in winter 2002 and 2007 (Fig. 12).

From Fig. 9a, it can be seen that in 2005 POC concentrations in the water column along the transect varied from $0.1 \mathrm{mg} \mathrm{L}^{-1}$ to $0.4 \mathrm{mg} \mathrm{L}^{-1}$. Higher POC concentrations were associated equally with water of higher salinity and with water of lower salinity, while higher CDOM concentrations, indicative of DOC, largely corresponded to low-salinity water. This implies that river runoff served as a source of DOC to the BKB. $p \mathrm{CO}_{2}$ along the transect ranged from a few hundreds to $4000 \mu \mathrm{atm}$, which implies super-saturation by up to 10 times relative to equilibrium with atmosphere. Higher $p \mathrm{CO}_{2}$ values were observed where salinity and POC levels were higher and $\mathrm{CDOM}$ was lower, suggesting that the predominant source of $\mathrm{CO}_{2}$ in the water column is not river runoff (Fig. 9b and e). We also found that when POC con-
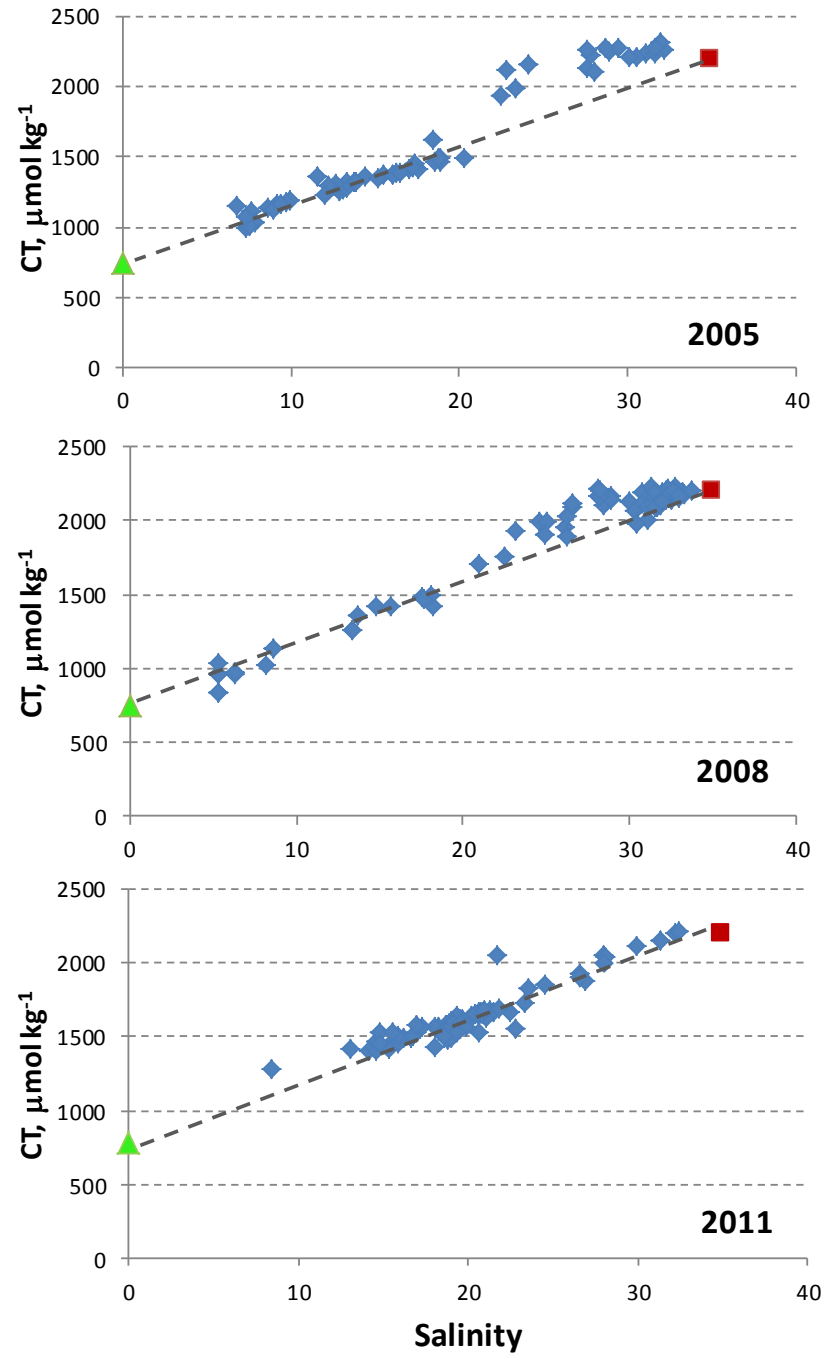

Fig. 8. Distribution of total inorganic carbon $\left(C_{\mathrm{T}}, \mu \mathrm{mol} \mathrm{kg}-1\right)$ vs. salinity: green triangle represents the Lena River end member ( $750 \mu \mathrm{mol} \mathrm{kg}{ }^{-1}$ vs. 0 salinity); red rectangle represents the Atlantic water end member $\left(2164 \mu \mathrm{mol} \mathrm{kg} \mathrm{kg}^{-1}\right.$ vs. 34.9 salinity).

centrations in waters of different salinities were comparable, higher $p \mathrm{CO}_{2}$ occurred where salinity was higher (Fig. 9c). $\mathrm{NO}_{3}^{-}$concentrations in the water column along the transect varied from negligible values up to $8 \mathrm{mg} \mathrm{L}^{-1}$. Higher $\mathrm{NO}_{3}^{-}$ concentrations were observed in saltier water and were associated with lower CDOM concentrations, suggesting that coastal erosion, rather than river runoff, is the $\mathrm{NO}_{3}^{-}$source (Fig. 9f). In 2011, relationships between studied parameters were similar to those observed in 2005 except for $p \mathrm{CO}_{2}$ detected in the water column (Fig. 10).

In summer 2011, sea water $p \mathrm{CO}_{2}$ varied from near saturated relative to the atmosphere $(\sim 400 \mu$ atm) to 2.5 times oversaturated $(900 \mu \mathrm{atm})$ - much lower than in summer 2005 , when sea water oversaturation reached 10 times relative to atmosphere. Note that the 2005 Lena River discharge was the 


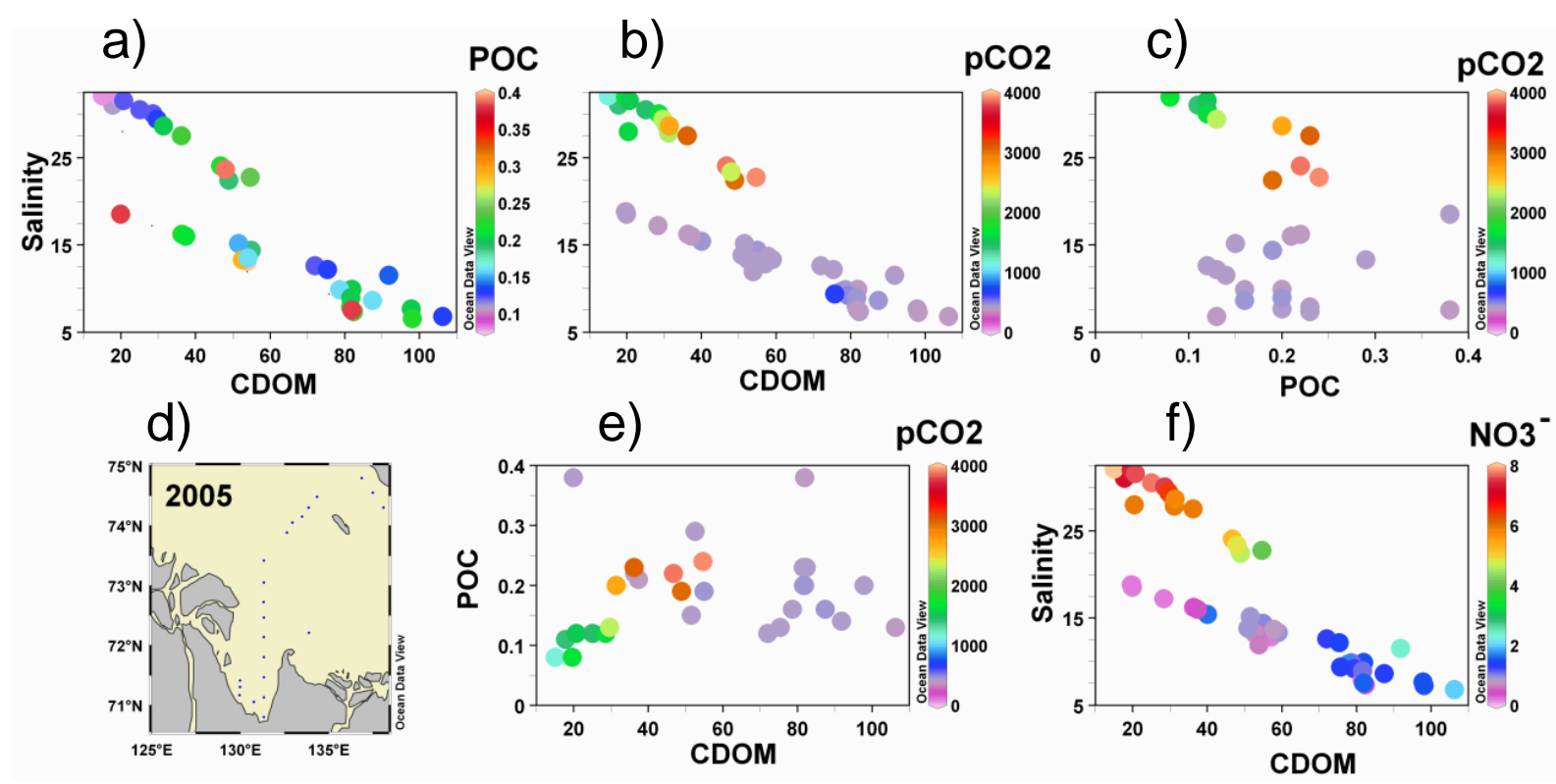

Fig. 9. Plots of particular organic carbon $\left(\mathrm{POC}, \mathrm{mg} \mathrm{L}^{-1}\right)$ (a) and partial pressure of $\mathrm{CO}_{2}\left(p \mathrm{CO}_{2}\right.$, $\mu$ atm) (b) color-coded by salinity and colored dissolved organic matter $\left(\mathrm{CDOM}, \mathrm{mg} \mathrm{m}^{-3}\right) ; \mathrm{pCO}_{2}$ color-coded by POC (c) and CDOM (e); nitrates $\left(\mathrm{NO}_{3}^{-}, \mu \mathrm{M}\right)$ color-coded by salinity and CDOM (f). Position of transect conducted in September 2005 is shown in (d).

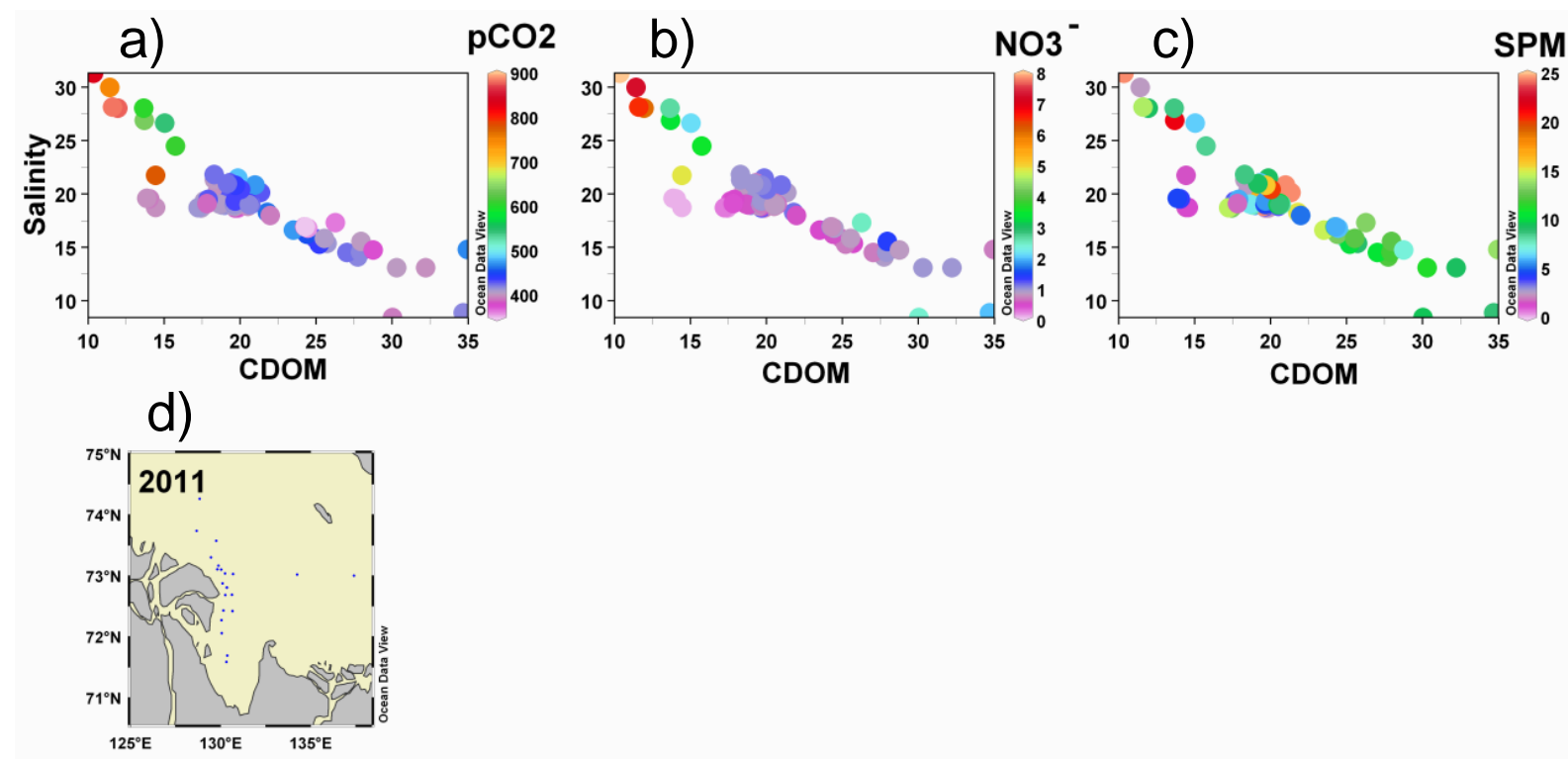

Fig. 10. Plots of $\mathrm{CO}_{2}$ partial pressure $\left(p \mathrm{CO}_{2}\right.$, $\mu$ atm $)$, color-coded by salinity and colored dissolved organic matter $\left(\mathrm{CDOM}, \mathrm{mg} \mathrm{m}^{-3}\right)(\mathbf{a})$; nitrates $\left(\mathrm{NO}_{3}^{-}, \mu \mathrm{M}\right)$ color-coded by salinity and CDOM (b); suspended particular matter (SPM, $\left.\mathrm{mg} \mathrm{L}^{-1}\right)$ color-coded by salinity and CDOM (c). Position of transect performed in 2011 is shown in (d).

lowest in the last ten years, while in 2011 it was about average volume. The observed difference in $p \mathrm{CO}_{2}$ between the two years was caused by strong 2011 winds $\left(10-20 \mathrm{~m} \mathrm{~s}^{-1}\right.$ ) which induced higher levels of coastal erosion and winddriven surface sediment resuspension (Heim et al., 2013) that contributed to the OM supply to the shelf water. At the same time more frequent and longer-lasting storms caused intense water mixing down to the very bottom and consequent release of $\mathrm{CO}_{2}$ to the atmosphere, allowing significant unloading of the water column $\mathrm{CO}_{2}$ (Fig. 11). In the winter, when the Lena River discharge was up to 10 times less than in summer, values of $p \mathrm{CO}_{2}$ in the water column remained comparable to those observed in summer 2005 (up to $4000 \mu \mathrm{atm}$, Fig. 12a and d). 

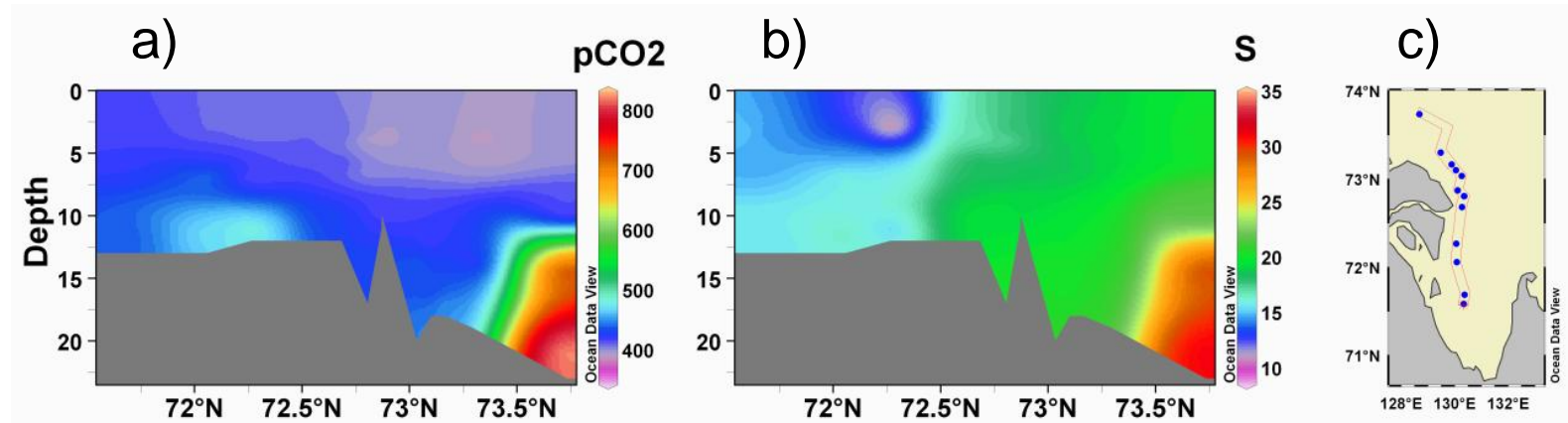

Fig. 11. Distribution of $\mathrm{CO}_{2}$ partial pressure $\left(p \mathrm{CO}_{2}, \mu \mathrm{atm}\right)$ (a) and salinity (b) in the water column of the Buor-Khaya Bay along transect observed in 2011. Position of transect is shown in (c).

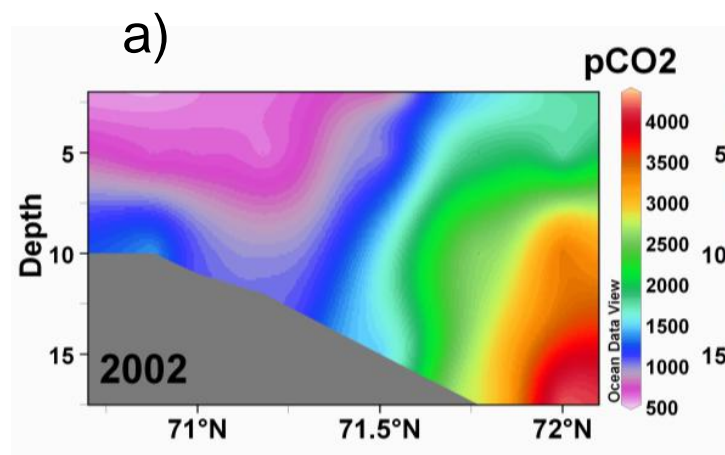

b)

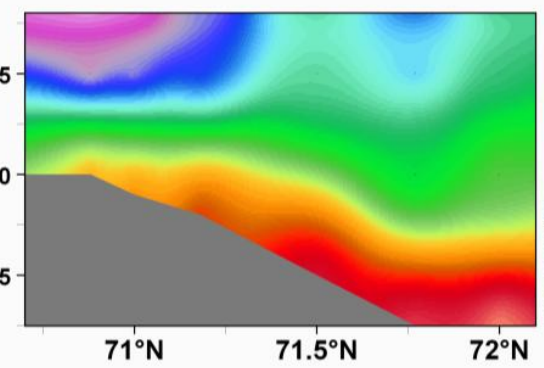

e)

$\mathrm{pCO} 2$
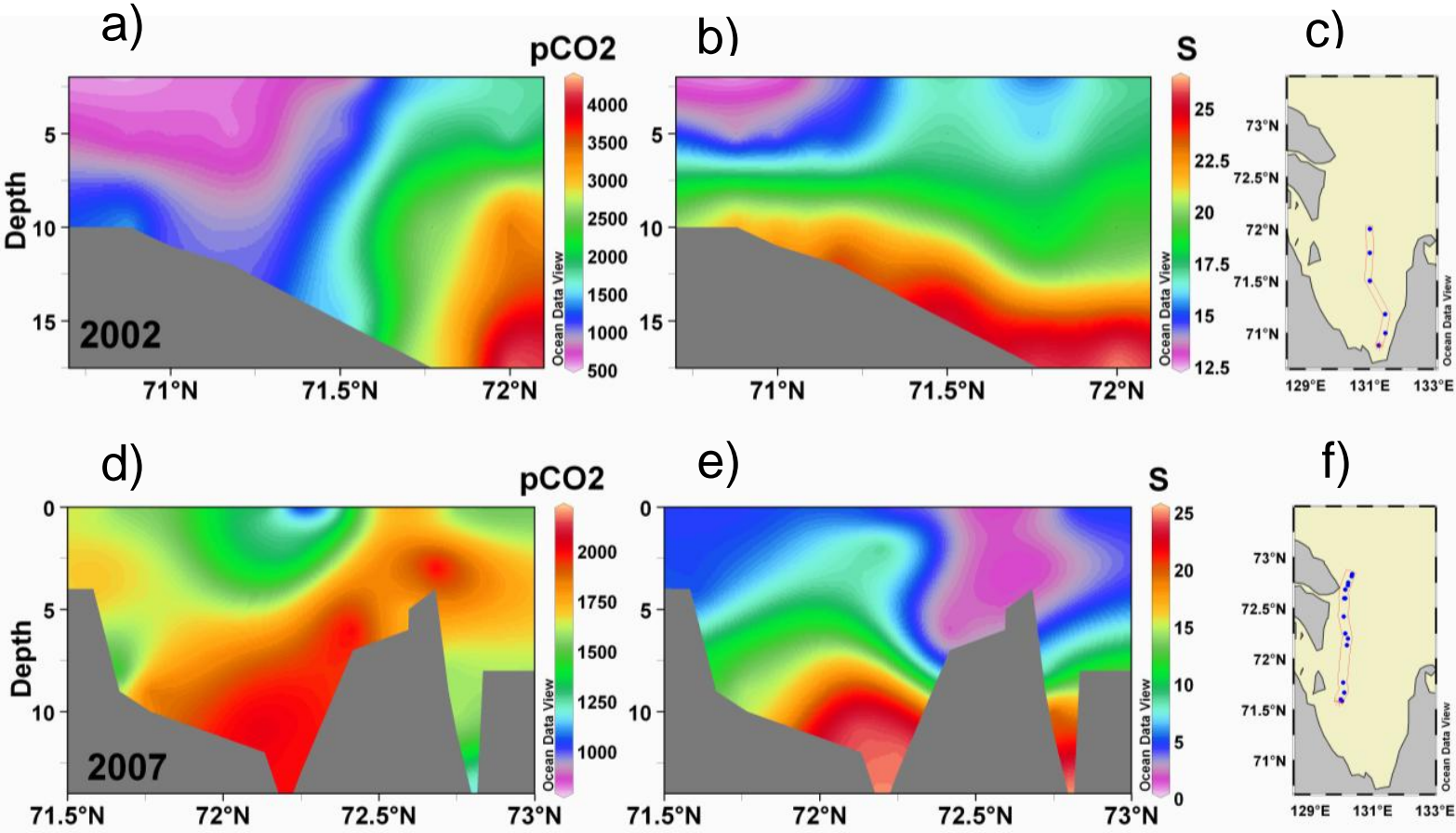

Fig. 12. Vertical distribution of $\mathrm{CO}_{2}$ partial pressure $\left(p \mathrm{CO}_{2}, \mu\right.$ atm $)(\mathbf{a}, 2002 ; \mathbf{d}, 2007)$ and salinity $(\mathbf{b}, 2002 ; \mathbf{e}, 2007)$ in the water column observed in the Buor-Khaya Bay in the winters of 2002 and 2007. Positions of transects are shown in (c) (2002) and (f) (2007).

As is clearly seen in Fig. 12, in winter the highest $p \mathrm{CO}_{2}$ values were associated with bottom water and could be attributed to the microbial degradation of $\mathrm{OM}$ that occurs at the water-sediment interface. Because the water column is better stratified in winter, vertical distribution of $p \mathrm{CO}_{2}$ in the water column reflected the stratification pattern. Because the $\mathrm{BKB}$ in winter is covered with sea ice, $\mathrm{CO}_{2}$ release to the atmosphere is restricted, allowing accumulation of $p \mathrm{CO}_{2}$ up to $5000 \mu$ atm (Semiletov et al., 2004), higher than $p \mathrm{CO}_{2}$ values measured in winter (1267-1579 $\mu \mathrm{atm})$ in the Lena Delta channels (Semiletov et al., 1996a, b).

Degradation of the OM resulting in increasing $p \mathrm{CO}_{2}$ is manifested by decreasing concentrations of $\mathrm{O}_{2}$. As is seen in Fig.13a, the most pronounced increase in $p \mathrm{CO}_{2}$ corre- sponded with a decrease in concentrations of $\mathrm{O}_{2}$ in the bottom water, where the highest $p \mathrm{CO}_{2}$ and the lowest levels of $\mathrm{O}_{2}$ were observed. Higher $p \mathrm{CO}_{2}$ in the bottom water resulted in lower $\mathrm{pH}$ or an acidified water column (Fig. 13b). The strong negative correlation observed between salinity and $\mathrm{pH}(R=-0.82, n=43$ in 2005) implies that coastal erosion/oxidation of eroded OM rather than river discharge is responsible for acidifying shelf water (Table 2). Intensive water mixing weakened the correlation $(R=-0.43, n=74)$ in 2011 as was described above.

We observed strong negative correlation between $p \mathrm{CO}_{2}$ and $\mathrm{O}_{2}(R=-0.97, n=43$ in 2005 and $R=-0.92, n=$ 74 in 2011), between $\mathrm{O}_{2}$ and $\mathrm{NO}_{3}^{-}(R=-0.87, n=43$ in 2005 and $R=-0.84, n=74$ in 2011), and between $\mathrm{O}_{2}$ and 

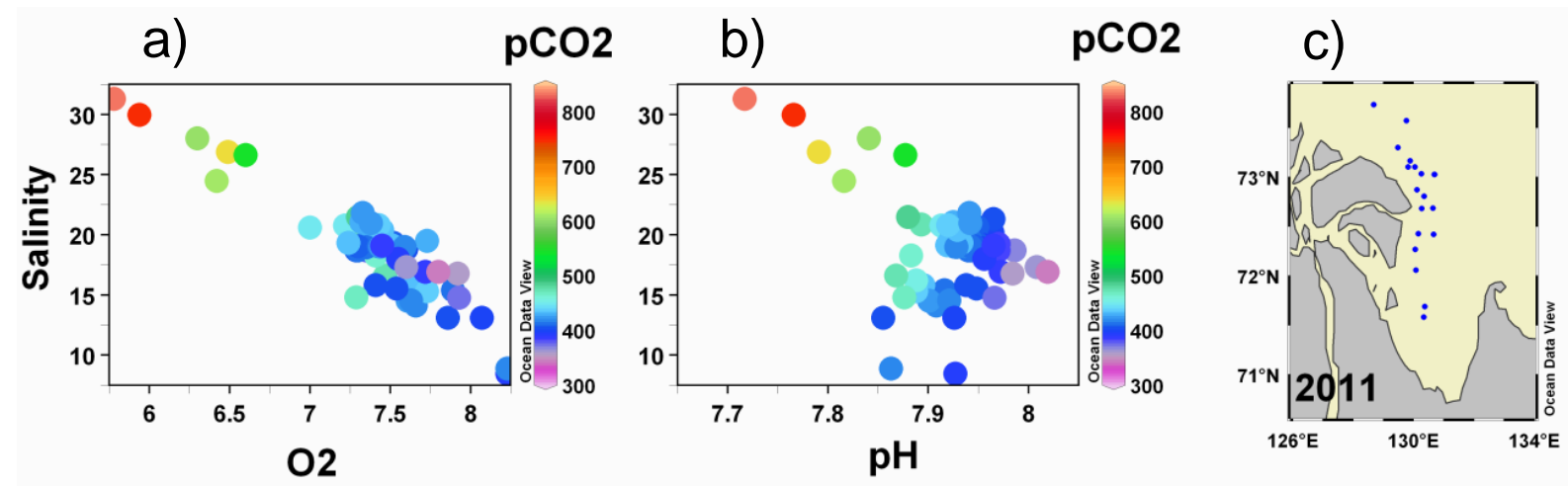

Fig. 13. Plots of $\mathrm{CO}_{2}$ partial pressure $\left(p \mathrm{CO}_{2}\right.$, $\mu$ atm), color-coded by salinity and dissolved oxygen $\left(\mathrm{O}_{2}, \mathrm{ml} \mathrm{L}^{-1}\right)(\mathbf{a}) ; p \mathrm{CO}_{2}$ color-coded by salinity and $\mathrm{pH}(\mathbf{b})$. Position of transects is shown in (c).

$\mathrm{PO}_{4}^{3-}(R=-0.7, n=43$ in 2005 and $R=-0.84, n=74$ in 2011). We found a strong positive correlation between $p \mathrm{CO}_{2}$ and $\mathrm{NO}_{3}^{-}(R=0.75, n=43$ in 2005 and $R=0.91, n=74$ in 2011), and between $p \mathrm{CO}_{2}$ and $\mathrm{PO}_{4}^{3-}(R=0.53, n=43$ in 2005 and $R=0.83, n=74$ in 2011) (Table 2 and Table 3), suggesting that high $p \mathrm{CO}_{2}$ is caused by in situ microbial OM (POC) decomposition in the water column.

Our data show that concentrations of nutrients $\left(\mathrm{NO}_{3}^{-}\right.$in the range of 5 to $8 \mu \mathrm{M}$ and $\mathrm{PO}_{4}^{3-}$ in the range of 0.45 to $1.45 \mu \mathrm{M}$ ) observed in the water column near Buor-Khaya Cape, known to be a landform subject to very high rates of coastal erosion, were significantly greater than values measured in the Lena River. Specifically, Lena River $\mathrm{NO}_{3}^{-}$concentrations ranged from 0.01 to $1.4 \mu \mathrm{M}$, and $\mathrm{PO}_{4}^{3-}$ concentrations ranged from 0.2 to $1.0 \mu \mathrm{M}$ (Lara et al., 1998). The vertical distribution of nutrients $\left(\mathrm{NO}_{3}^{-}, \mathrm{PO}_{4}^{3-}\right), p \mathrm{CO}_{2}$, and oxygen saturation in the BKB area, as seen in Fig. 14, also demonstrate that degradation of the eroded terrestrial OM rather than river-transported $\mathrm{OM}$ serves as the predominant source of nutrients to the BKB.

Concentrations of nutrients in the Lena River water column imply primary production potential in the euphotic layer. Nevertheless, it was reported that primary production in the BKB was higher ( 75 to $640 \mathrm{mg} \mathrm{C} \mathrm{m}^{-2}$ day $^{-1}$ ) than in the Lena River/Delta (50 to only $160 \mathrm{mg} \mathrm{C} \mathrm{m}^{-2} \mathrm{day}^{-1}$ ), but was limited by low water transparency caused by the extremely high water turbidity (Sorokin and Sorokin, 1996). Another reason for the low transparency and primary production could be high CDOM values; values are one order of magnitude higher in the Lena River (up to $100-110 \mathrm{mg} \mathrm{m}^{-3}$ ), in the Laptev Sea (up to $50-70 \mathrm{mg} \mathrm{m}^{-3}$ ), and in the western part of the East Siberian Sea $\left(>30 \mathrm{mg} \mathrm{m}^{-3}\right)$ than in the eastern part of the East Siberian Sea $\left(5 \mathrm{mg} \mathrm{m}^{-3}\right)$. This is because the Laptev Sea and the western East Siberian Sea are strongly influenced by riverine runoff enriched in humic substances (Semiletov et al., 2005, 2007; Pipko et al., 2008, 2011a; Pugach and Pipko, 2013). Low transparencies are reflected by in situ Secchi depths of less than $0.5 \mathrm{~m}$ near the Bykovsky chan- nel outlet (summer 2008, by Heim et al., 2013) and 0.2-0.4 m in Neelov Bay and the Bykovsky channel (summer 2003, authors' data).

These data are important to take into consideration while evaluating the satellite data. Based on satellite data, it was concluded that increases in net primary production (NPP) occurred in the eastern Arctic Ocean over the 12-year study period (1998 to 2009). The largest increase in NPP in the eastern Arctic Ocean observed between 1998 and 2009 was reported in the oligotrophic Siberian shelf (from $101 \pm 15.8$ in the Siberian sector to $121 \pm 20.2 \mathrm{~g} \mathrm{C} \mathrm{m}^{-2} \mathrm{yr}^{-1}$ in the Laptev, or $+135 \%$; Arrigo and van Dijken, 2011). At the same time, in the most productive western sector, reported NPP ranged from $71.3 \pm 11.0 \mathrm{~g} \mathrm{C} \mathrm{m}^{-2} \mathrm{yr}^{-1}$ in the Beaufort to $96.9 \pm 7.4 \mathrm{~g} \mathrm{C} \mathrm{m}^{-2} \mathrm{yr}^{-1}$ in the Chukchi seas. Nevertheless, field data show that NPP in the highly productive Chukchi Sea is one to two orders of magnitude higher (up to 200$400 \mathrm{~g} \mathrm{C} \mathrm{m}^{-2} \mathrm{yr}^{-1}$ ) than in the oligotrophic Laptev Sea and western part of the East Siberian Sea (Walsh et al., 1989; Sorokin and Sorokin, 1996). Thus, the proposed NPP increase based on interpretation of satellite data must be validated with observational data (Heim et al., 2013; Fichot et al., 2013). Meanwhile, the observed increase in the Lena River discharge of up to $37 \%$ (2008) since the 1990s suggests that increased levels of annual primary production could be explained by an increasing load of humic acids delivered to shelf water; the color resulting from the presence of CDOM in this water mimics the color resulting from the presence of Chl $a$ when seen from space.

\subsection{Buor-Khaya Bay, its coastal zone, and Muostakh Island as a source of $\mathrm{CO}_{2}$ emissions to the atmosphere}

The multi-year investigation of $\mathrm{BKB} p \mathrm{CO}_{2}$ shows that "strong" oversaturation of the surface water predominantly occurred in the eastern part of the study area (Fig. 15), while sometimes a "slight" oversaturation was observed in 
Table 2. Correlation matrix of the environmental parameters observed in the Buor-Khaya Bay in September 2005 ( $n=43)$.

\begin{tabular}{|c|c|c|c|c|c|c|c|c|c|c|c|c|}
\hline & $T$ & $S$ & $A_{\mathrm{T}}$ & $\mathrm{pH}$ & $p \mathrm{CO}_{2}$ & $\mathrm{O}_{2}$ & $\mathrm{PO}_{4}^{3-}$ & $\mathrm{Si}$ & $\mathrm{NO}_{3}^{-}$ & CDOM & POC & SPM \\
\hline$T$ & 1 & & & & & & & & & & & \\
\hline$S$ & -0.97 & 1 & & & & & & & & & & \\
\hline$A_{\mathrm{T}}$ & -0.97 & 0.99 & 1 & & & & & & & & & \\
\hline $\mathrm{pH}$ & 0.74 & -0.82 & -0.84 & 1 & & & & & & & & \\
\hline$p \mathrm{CO}_{2}$ & -0.69 & 0.77 & 0.80 & -0.98 & 1 & & & & & & & \\
\hline $\mathrm{O}_{2}$ & 0.82 & -0.88 & -0.90 & 0.98 & -0.97 & 1 & & & & & & \\
\hline $\mathrm{PO}_{4}^{3-}$ & -0.91 & 0.88 & 0.88 & -0.62 & 0.53 & -0.70 & 1 & & & & & \\
\hline $\mathrm{Si}^{4}$ & 0.09 & -0.07 & 0.00 & -0.38 & 0.38 & -0.30 & -0.04 & 1 & & & & \\
\hline $\mathrm{NO}_{3}^{-}$ & -0.93 & 0.93 & 0.95 & -0.82 & 0.75 & -0.87 & 0.92 & 0.18 & 1 & & & \\
\hline CDOM & 0.89 & -0.91 & -0.87 & 0.66 & -0.59 & 0.71 & -0.75 & 0.37 & -0.76 & 1 & & \\
\hline POC & 0.27 & -0.26 & -0.31 & 0.11 & -0.09 & 0.18 & -0.44 & -0.08 & -0.37 & 0.05 & 1 & \\
\hline SPM & -0.16 & 0.16 & 0.12 & -0.22 & 0.26 & -0.19 & -0.03 & -0.14 & 0.07 & -0.27 & 0.70 & 1 \\
\hline
\end{tabular}

Table 3. Correlation matrix of the environmental parameters observed in the Buor-Khaya Bay in September $2011(n=74)$.

\begin{tabular}{lrrrrrrrrrrr}
\hline & $T$ & $S$ & $A_{\mathrm{T}}$ & $\mathrm{pH}$ & $p \mathrm{CO}_{2}$ & $\mathrm{O}_{2}$ & $\mathrm{PO}_{4}^{3-}$ & $\mathrm{Si}$ & $\mathrm{NO}_{3}^{-}$ & $\mathrm{CDOM}$ & $\mathrm{SPM}$ \\
\hline$T$ & 1 & & & & & & & & & & \\
$S$ & -0.26 & 1 & & & & & & & & & \\
$A_{\mathrm{T}}$ & -0.33 & 0.99 & 1 & & & & & & & & \\
$\mathrm{pH}$ & 0.31 & -0.43 & -0.42 & 1 & & & & & & & \\
$p \mathrm{CO}_{2}$ & -0.42 & 0.81 & 0.82 & -0.81 & 1 & & & & & & \\
$\mathrm{O}_{2}$ & 0.35 & -0.93 & -0.94 & 0.61 & -0.92 & 1 & & & & & \\
$\mathrm{PO}_{4}^{3-}$ & -0.48 & 0.72 & 0.74 & -0.61 & 0.83 & -0.84 & 1 & & & & \\
$\mathrm{Si}^{3-}$ & -0.22 & -0.62 & -0.58 & -0.26 & -0.16 & 0.44 & -0.23 & 1 & & & \\
$\mathrm{NO}_{3}^{-}$ & -0.68 & 0.71 & 0.75 & -0.73 & 0.91 & -0.84 & 0.85 & -0.02 & 1 & & \\
$\mathrm{CDOM}$ & 0.10 & -0.91 & -0.88 & 0.24 & -0.63 & 0.79 & -0.60 & 0.73 & -0.53 & 1 & \\
$\mathrm{SPM}$ & -0.32 & 0.27 & 0.25 & -0.33 & 0.36 & -0.33 & 0.46 & -0.04 & 0.33 & -0.15 & 1 \\
\hline
\end{tabular}

the small area adjacent to the Lena River delta, perhaps as a result of lower $p \mathrm{CO}_{2}$ values in the river water followed by the enhanced uptake of $\mathrm{CO}_{2}$ by photosynthesis (Sorokin and Sorokin, 1996).

Surface water that is oversaturated with $\mathrm{CO}_{2}$ serves as a source of $\mathrm{CO}_{2}$ to the atmosphere. As is shown in Fig. 16, the BKB surface is a source of $\mathrm{CO}_{2}$ to the atmosphere with rates varying from near zero to $56 \mathrm{mmol} \mathrm{m}^{-2} \mathrm{day}^{-1}$ in 2005 , and from 1 to $95 \mathrm{mmol} \mathrm{m}^{-2} \mathrm{day}^{-1}$ in 1999 . In winter $p \mathrm{CO}_{2}$ remained high, exceeding the summer values, due to restricted ventilation of the ice-covered water column (Semiletov et al., 2004, 2007). The bottom water is oversaturated with $\mathrm{CO}_{2}$ year-round and the potential exists for the $\mathrm{CO}_{2}$ to be released into the atmosphere north off the Lena Delta through open flaw polynyas because of deep convection (Shakhova et al., 2010a).

It was reported that the area surrounding Muostakh Island experiences coastal erosion of up to $15-20 \mathrm{~m}$ during only a few summertime weeks, much higher than the average coastal erosion rates in the area (Grigoriev and Kunitsky, 2000). It has recently been elucidated that a significant fraction of old carbon activated by erosion of coastal permafrost is released directly to the atmosphere as $\mathrm{CO}_{2}$ as a result of sub-aerial degradation (Vonk et al., 2012), in contrast to the prior assumption that all thawed and erosion-mobilized OC is flushed into the sea (Stein and Macdonald, 2004). Fig. 17 presents observational data on $\mathrm{CO}_{2}$ emissions from the thawing ice complex measured by the same technique in September 2006 (Vonk et al., 2012) and September 2009 along similar transects across the northern cape of Muostakh Island.

As seen in Fig. 17, the $\mathrm{CO}_{2}$ fluxes from a thawed IC in the BKB area (Muostakh Island) measured in late September 2009 were in the same range (24$\left.430 \mathrm{mmol} \mathrm{m}^{-2} \mathrm{day}^{-1}\right)$ as fluxes measured in early September 2006 (9-439 $\mathrm{mmol} \mathrm{m}^{-2} \mathrm{day}^{-1}$; Vonk et al., 2012). Mean values of atmospheric $\mathrm{CO}_{2}$ emissions from the thawed IC on the northern cape of Muostakh Island (Fig. 2) varied from 75.7 to $101 \mathrm{mmol} \mathrm{m}^{-2}$ day $^{-1}$ in two years (September 2006 and 2009), suggesting that at the time of observations the eroded coastal area served as a more significant source of $\mathrm{CO}_{2}$ to the atmosphere than the tundra (mean value $=22.7 \mathrm{mmol} \mathrm{m}^{-2} \mathrm{day}^{-1}$ ) on the neighboring Primorsky coastal plain (high Arctic tundra near Tiksi) in September 2006 (Table 4). The focus of this manuscript is not 


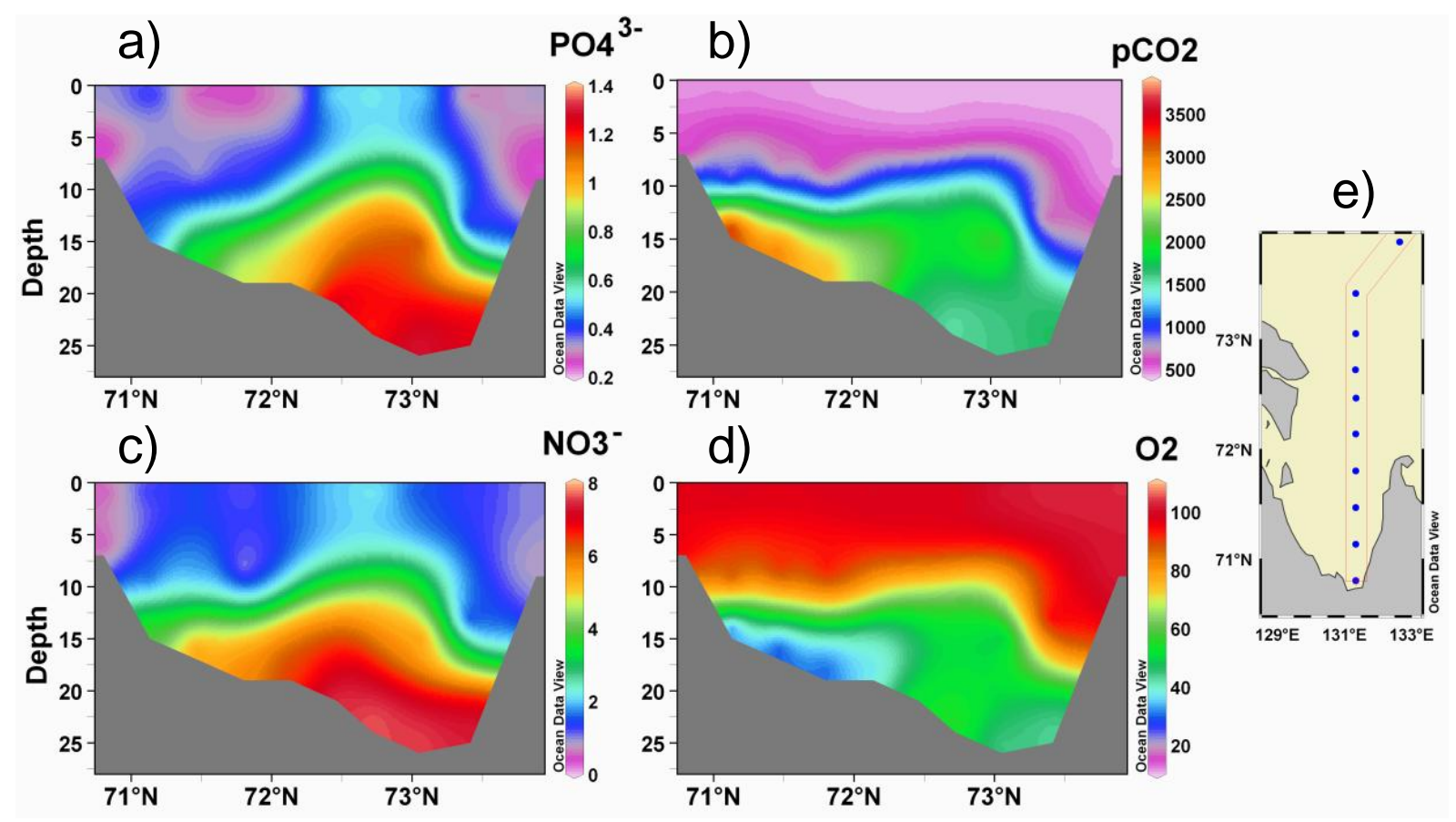

Fig. 14. Vertical distribution of phosphates $\left(\mathrm{PO}_{4}^{3-}, \mu \mathrm{M}\right)(\mathbf{a})$, partial pressure of $\mathrm{CO}_{2}\left(p \mathrm{CO}_{2}, \mu\right.$ atm $)(\mathbf{b})$, nitrates, $\left(\mathrm{NO}_{3}^{-}\right.$, $\left.\mu \mathrm{M}\right)(\mathbf{c})$, and oxygen saturation state $\left(\mathrm{O}_{2}, \%\right)(\mathbf{d})$ in the water column observed in the Buor-Khaya Bay in summer 2005. Transect position is shown in (e).
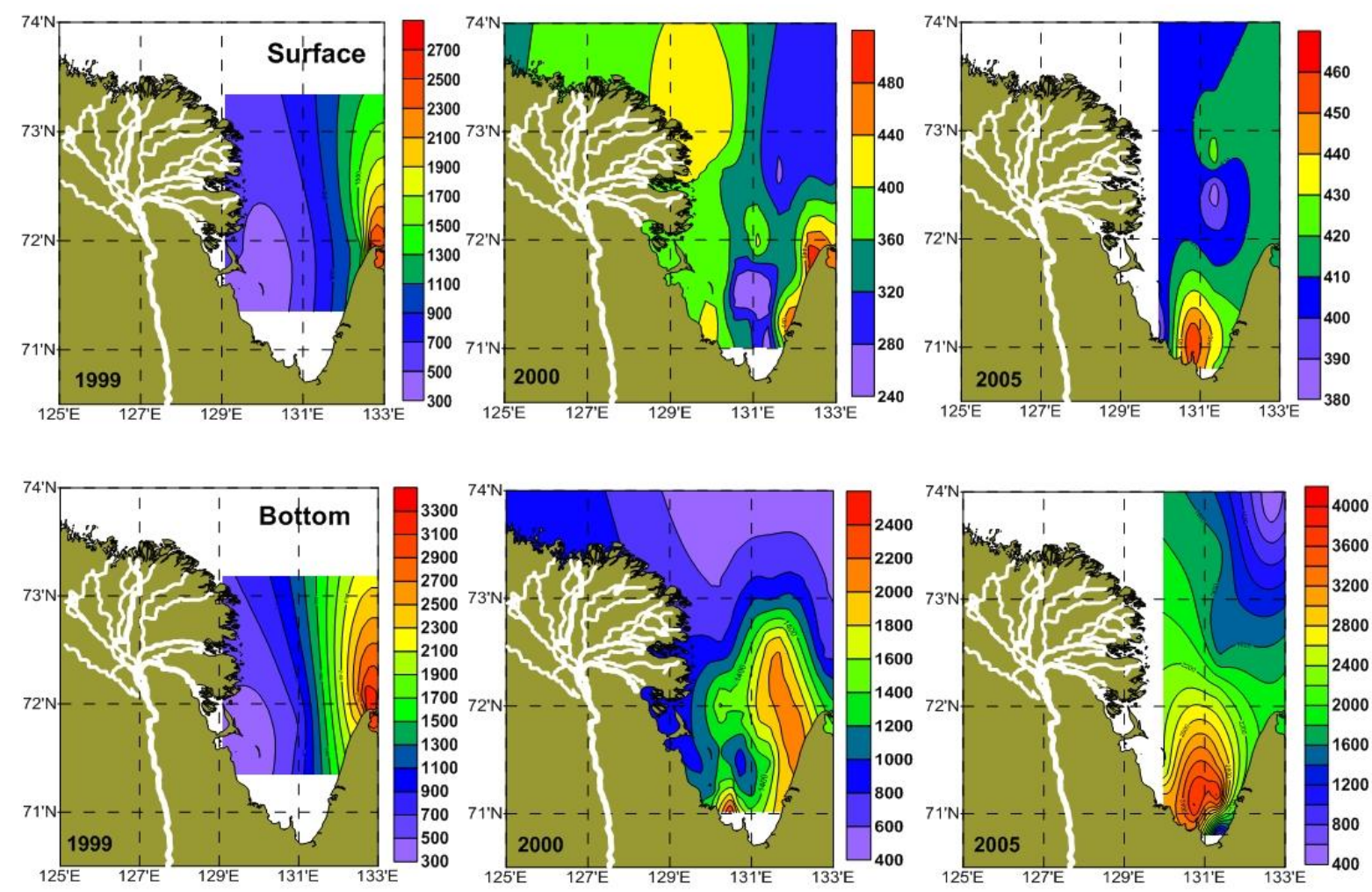

Fig. 15. Distribution of $\mathrm{CO}_{2}$ partial pressure $\left(p \mathrm{CO}_{2}, \mu \mathrm{atm}\right)$ in the surface and bottom water layers of the Buor-Khaya Bay observed in 1999 , 2000 and 2005. 

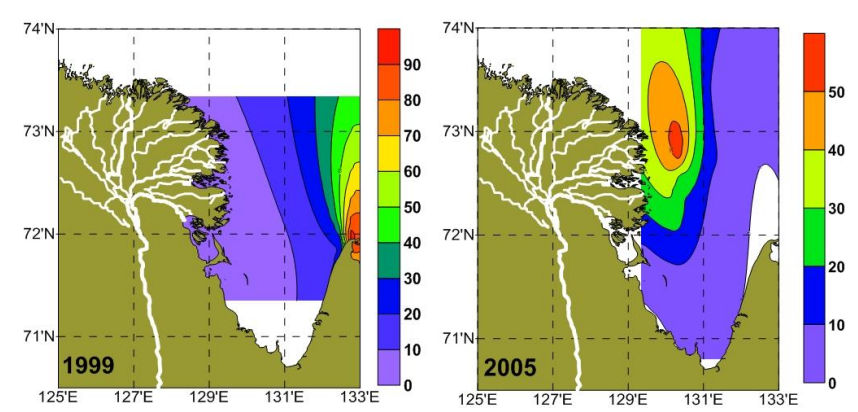

Fig. 16. Distribution of sea-air $\mathrm{CO}_{2}$ fluxes $\left(F_{\mathrm{CO}_{2}}\right.$, mmol m${ }^{-2}$ day $^{-1}$ ) (color code) in the Buor-Khaya Bay observed in September 1999 (left panel) and September 2005 (right panel).

Table 4. Mean atmospheric $\mathrm{CO}_{2}$ emission $\left(\mathrm{F}_{\mathrm{CO}_{2}}\right)$ from the shallow Laptev Sea, its eroded coast, and the adjacent tundra.

\begin{tabular}{lc}
\hline & $\begin{array}{l}F_{\mathrm{CO}_{2}}(\mathrm{mmol} \\
\mathrm{m}^{-2} \text { day }\end{array}$ \\
\hline Muostakh I., eroded coast, September 2006 $(n=41)$ & $75.7 \pm 119.8$ \\
Muostakh I., near-shore zone, September 2006 $(n=6)$ & $25.3 \pm 8.9$ \\
Muostakh I., upland tundra, September 2006 $(n=15)$ & $17.2 \pm 8.7$ \\
Muostakh I., eroded coast, September 2009 $(n=16)$ & $101 \pm 134$ \\
Muostakh I., near-shore zone, September 2009 $(n=5)$ & $40.9 \pm 6.9$ \\
Muostakh I., upland tundra, September 2009 $(n=7)$ & $32.7 \pm 19.5$ \\
Primorsky tundra, September 2006 $(n=31)$ & $22.7 \pm 24.9$ \\
Shallow Laptev Sea, September 1999 $(n=36)$ & $7.2 \pm 17.7$ \\
Shallow Laptev Sea, September 2005 $(n=22)$ & $7.8 \pm 12.2$ \\
Shallow Laptev Sea, September 2011 $(n=22)$ & $0.6 \pm 0.4$ \\
\hline
\end{tabular}

on a description of the Primorsky coastal plain sites, but the bulk and molecular analyses made along the flux transects across the Muostakh Island can be found elsewhere (Vonk et al., 2012). Note that mean values of soil respiration observed from the non-disturbed Muostakh Island "upland" tundra in September 2006 and 2009 (17.2 and $32.7 \mathrm{mmol} \mathrm{m}^{-2}$ day $^{-1}$, respectively) were similar with $\mathrm{CO}_{2}$ efflux from the neighboring Primorsky coastal plain (Table 4).

The $\mathrm{CO}_{2}$ fluxes measured in the shallow Laptev Sea were much lower than those observed from the thawing ice complex but were in the range of $\mathrm{CO}_{2}$ fluxes (1$95 \mathrm{mmol} \mathrm{m}^{-2} \mathrm{day}^{-1}$ ) reported for the BKB area (Fig. 16) and other shallow areas of the ESAS impacted by export of eroded carbon (Pipko et al., 2008, 2011a; Semiletov et al., 2011, 2012). In terms of inter-annual variability, mean $\mathrm{CO}_{2}$ fluxes observed at near-shore sea sites in September 2009 $\left(40.9 \mathrm{mmol} \mathrm{m}^{-2} \mathrm{day}^{-1}\right)$ were higher than in September 2006 $\left(25.3 \mathrm{mmol} \mathrm{m}^{-2} \mathrm{day}^{-1}\right)$. Mean values of $\mathrm{CO}_{2}$ emission from the shallow Laptev Sea were similar in September 1999 and 2005 (7.2 and $7.8 \mathrm{mmol} \mathrm{m}^{-2} \mathrm{day}^{-1}$, respectively), while the $\mathrm{CO}_{2}$ efflux can be one order lower after the strong storm such as in September 2011 (Table 4).

\section{Conclusions}

Based on our multi-year data (1999-2011), we suggest that in the BKB, heterotrophic processes associated with river discharge and coastal erosion drive OC input and transformation, dynamics of nutrients, and carbon stocks in the water column. Specifically:

- Input of terrestrially borne OC varies seasonally and inter-annually and is largely determined by rates of coastal erosion and river discharge. The latter has increased since the 1990 s by $\sim 11 \%$.

- Two different BKB sedimentation regimes were revealed: Type 1 (erosion accumulation) and Type 2 (accumulation). Under Type 1 erosion accumulation conditions, terrigenous sources of SPM and POC stem predominantly from thermal erosion of coastal ice complexes, river discharge, and remobilized bottom sediments. In Type 2 (summer), river alluvium is the major SPM and POC source. In Type 2 (winter), combined terrigenous and marine-biogenic SPM and POC sources are dominating due to relatively low overall terrigenous input. A Type 1 sedimentation regime occurs more often and is believed to be the quantitatively most important mechanism for SPM and POC delivery to the BKB. The mean SPM concentration observed in the BKB under a Type 1 regime was one order of magnitude greater than the mean concentration of SPM $\left(\sim 20 \mathrm{mg} \mathrm{L}^{-1}\right)$ observed along the Lena River stream in summer 2003.

- Higher levels of $p \mathrm{CO}_{2}$, higher concentrations of nutrients, and lower levels of oxygen saturation were observed in the bottom water near the eroded coasts; this implies that coastal erosion and subsequent oxidation of eroded OM rather than the Lena River serves as the predominant source of nutrients to the BKB area and the adjacent part of the Laptev Sea.

- Oversaturation of surface water with $p \mathrm{CO}_{2}$ in the BKB area and the shallow ESAS ( $<70 \mathrm{~m}$ in depth) implies that the sea surface is a significant regional source of $\mathrm{CO}_{2}$ to the atmosphere; $\mathrm{CO}_{2}$ fluxes from sea water into the atmosphere $\left(1-95 \mathrm{mmol} \mathrm{m}^{-2} \mathrm{day}^{-1}\right)$ are determined by specific features of hydrology and wind conditions, which change seasonally and inter-annually.

- The $\mathrm{CO}_{2}$ fluxes measured from a thawed ice complex in the BKB area (Muostakh Island) in late September 2009 were in the same range $\left(24-430 \mathrm{mmol} \mathrm{m}^{-2} \mathrm{day}^{-1}\right)$ as fluxes measured in early September 2006 (9$439 \mathrm{mmol} \mathrm{m}^{-2}$ day $^{-1}$; Vonk et al., 2012). Mean values of atmospheric $\mathrm{CO}_{2}$ emissions from a thawed coastal ice complex in the BKB area varied from 75.7 to $101 \mathrm{mmol} \mathrm{m}^{-2}$ day $^{-1}$ in two years (September 2006 and 2009), suggesting that at the time of observations the eroded coastal area served as a more significant 
a)

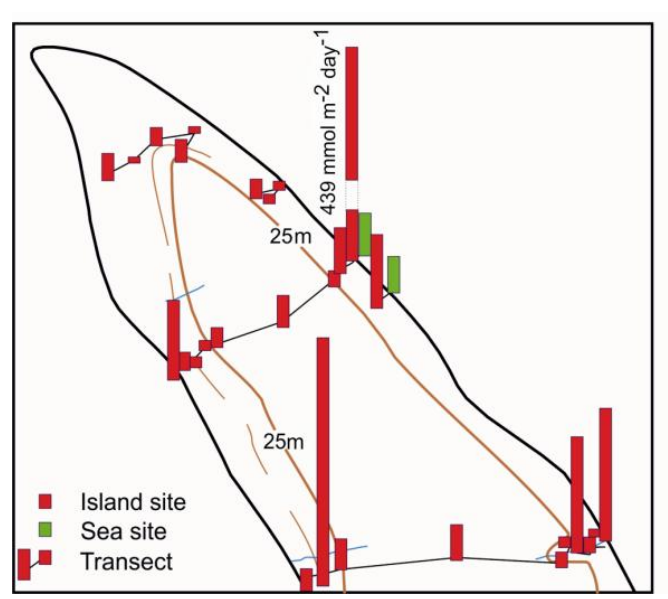

b)

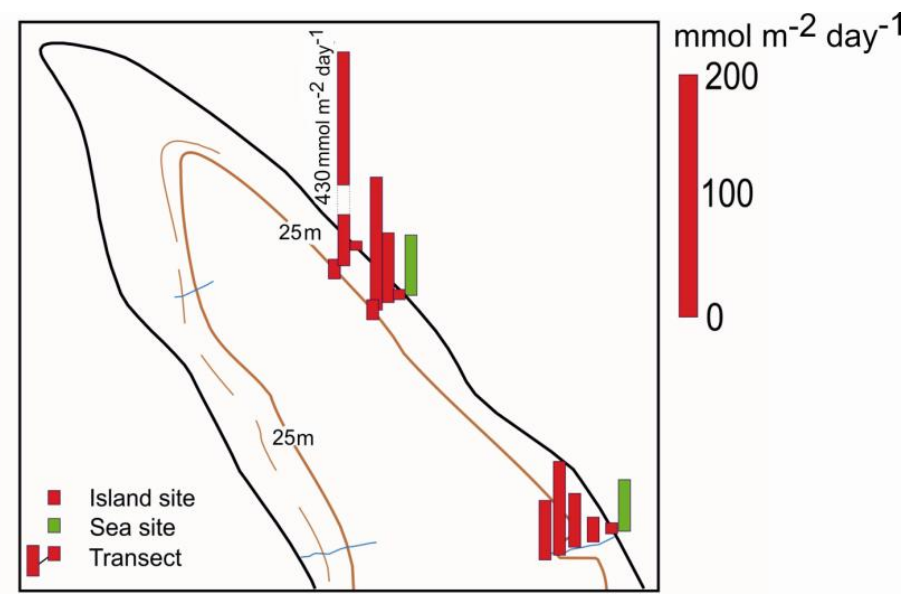

Fig. 17. Distribution of $\mathrm{CO}_{2}$ out-gassing from Muostakh Island sites (red columns) and from sea sites (green columns) in September 2006 (a), and in September 2009 (b).

source of $\mathrm{CO}_{2}$ to the atmosphere than the tundra (mean value $=22.7 \mathrm{mmol} \mathrm{m}^{-2} \mathrm{day}^{-1}$ ) on the neighboring Primorsky coastal plain.

- High CDOM values observed in the western part of the Laptev Sea (up to $50-70 \mathrm{mg} \mathrm{m}^{-3}$ ), and in the western part of the East Siberian Sea $\left(>30 \mathrm{mg} \mathrm{m}^{-3}\right)$ are resultant from increased discharge of the Lena River loaded with CDOM at values as high as up to $110 \mathrm{mg} \mathrm{m}^{-3}$ and enriched in humic substances; the color resulting from the presence of CDOM in this water likely mimics the color resulting from the presence of Chl $a$ when seen from space - this could explain recently proposed increase in NPP rates reported for these areas of the ESAS derived based on interpretation of satellite data.

The BKB area and the adjacent part of the Laptev Sea can be employed as an integrator of ongoing changes in the surrounding environment. These changes create a terrestrial or exogenous signal generated by increasing coastal and bottom erosion (increasing export of terrestrial POC to the Arctic Ocean), increasing river runoff (increasing export of terrestrial DOC/humic acids/CDOM to the Arctic Ocean), and involvement of terrestrial carbon in the modern biogeochemical cycle. Thus, we suggest that under ongoing changes, more nutrients, products of eroded OC transformation and river transport, will be delivered to the Arctic Ocean with its shrinking ice cover, potentially increasing primary production outside of the shallow ESAS. At the same time, because the ESAS is characterized by very low transparency which limits euphotic layer thickness, excessive $p \mathrm{CO}_{2}$ will not be utilized by photosynthesis but will rather be emitted to the atmosphere at increasing rates, affecting regional $\mathrm{CO}_{2}$ balance.
Acknowledgements. Authors are thankful to two anonymous reviewers and Quest Editor Paul Overduin for their useful and constructive comments. This work was supported by the International Arctic Research Center (IARC) of the University of Alaska Fairbanks; the Far Eastern Branch of the Russian Academy of Sciences (FEBRAS); the Cooperative Institute for Arctic Research, through NOAA Cooperative Agreement NA17RJ1224; the U.S. National Science Foundation (nos. OPP-0327664, OPP-0230455, ARC-1023281, ARC-0909546); the NOAA OAR Climate Program Office (NA08OAR4600758); the Japan Agency for Marine-Earth Science and Technology (JAMSTEC); and the Russian Foundation for Basic Research (nos. 08-05-00184, 08-05-00191, 10-05-00996, 11-05-00781, 11-05-12021, 11-05-12027, 11-05-12028, 11-0512032, 12-05-31097, 12-05-31307). The International Siberian Shelf Study (ISSS) 2008 cruises were carried out with logistic support from the Knut and Alice Walenberg Foundation, from FEBRAS, and from the Swedish Polar Research Secretariat. We thank Valentin Sergienko, Gunter Weller, Syun Akasofu, Larry Hinzman, and Orjan Gustafsson for their cooperation and support of our work in the Siberian Arctic. We acknowledge Dmitry Mel'nichenko, Head of Tiksi Hydrobase, and Elena Streletskaya, Director of the Scientific Agency Arctic Marine Exploration, for their logistical support. We thank Candace O'Connor for English editing.

Edited by: P. Overduin 


\section{References}

ACIA: Impacts of a Warming Arctic: Arctic Climate Impact Assessment, Cambridge University Press, Cambridge, 139 pp., 2004.

Alling, V., Sánchez-García, L., Porcelli, D., Pugach, S., Vonk, J., van Dongen, B., Mörth, C. M., Anderson, L. G., Sokolov, A., Andersson, P., Humborg, C., Semiletov, I., and Gustafsson, Ö.: Nonconservative behavior of dissolved organic carbon across the Laptev and East Siberian seas, Global Biogeochem. Cy., 24, GB4033, doi:10.1029/2010GB003834, 2010.

AMAP: Snow, Water, Ice and Permafrost in the Arctic (SWIPA): Climate Change and the Cryosphere. Arctic Monitoring and Assessment Programme (AMAP), Oslo, Norway, 538 pp., 2012.

Amon, R. M. W. and Benner, R.: Bacterial utilization of different size classes of dissolved organic matter, Limnol. Oceanogr., 41, 41-51, 1996a.

Amon, R. M. W. and Benner, R.: Photochemical and microbial consumption of dissolved organic carbon and dissolved oxygen in the Amazon River system, Geochim. Cosmochim. Ac., 60, 10, 1783-1792, 1996b.

Anderson, L. G., Jutterström, S., Hjalmarsson, S., Wahlström, I., and Semiletov, I.: Out-gassing of $\mathrm{CO}_{2}$ from Siberian Shelf seas by terrestrial organic matter decomposition, Geophys. Res. Lett., 36, L20601, doi:10.1029/2009GL040046, 2009.

Anderson, L. G., Björk, G., Jutterström, S., Pipko, I., Shakhova, N., Semiletov, I., and Wåhlström, I.: East Siberian Sea, an Arctic region of very high biogeochemical activity, Biogeosciences, 8, 1745-1754, doi:10.5194/bg-8-1745-2011, 2011.

Arrigo, K. R. and van Dijken, G.: Secular trends in Arctic Ocean net primary production, J. Geophys. Res., 116, C09011, doi:10.1029/2011JC007151, 2011.

Belzile, C. C., Roesler, S., Christensen, J. P., Shakhova, N., and Semiletov, I.: Fluorescence measured using the WETStar DOM fluorometer as a proxy for dissolved matter absorption, Estuar. Coast. Shelf Sci., 67, 41-49, 2006.

Boucsein, B., Fahl, K., and Stein, R.: Variability of river discharge and Atlantic-water inflow at the Laptev Sea continental margin during the past 15,000 years: Implications from maceral and biomarker records, Int. J. Earth Sci., 89, 578-591, 2000.

Bruevich, S. V.: Instruction for Chemical Investigation of Seawater, Glavsevmorput, Moscow, 83 pp., 1944 (in Russian).

Canadell, J. G. and Raupach, M. R.: Land carbon cycle feedbacks, in: Sommerkorn, M. and Hassol, S. J. (Eds.): Arctic Climate Feedbacks: Global Implications, WWF International Arctic Programme, Oslo, 70-80, 2009.

Charkin, A. N., Dudarev, O. V., Semiletov, I. P., Kruhmalev, A. V., Vonk, J. E., Sánchez-García, L., Karlsson, E., and Gustafsson, Ö.: Seasonal and interannual variability of sedimentation and organic matter distribution in the Buor-Khaya Gulf: the primary recipient of input from Lena River and coastal erosion in the southeast Laptev Sea, Biogeosciences, 8, 2581-2594, doi:10.5194/bg8-2581-2011, 2011.

Cooke, M. P., van Dongen, B., Talbot, H., Semiletov, I., Shakhova, N., Guo, L., and Gustafsson, Ö.: Bacteriohopanepolyol biomarker composition of organic matter exported to the Arctic Ocean by seven of the major Arctic rivers, Org. Geochem., 40, 1151-1159, doi:10.1016/j.orggeochem.2009.07.014, 2009.

Cooper, L. W., Benner, R., McClelland, J. W., Peterson, B. J., Holmes, R. M., Raymond, P. A., Hansell, D. A., Grebmeier, J. M., and Codispoti, L. A.: Linkages among runoff, dissolved or- ganic carbon, and the stable oxygen isotope composition of seawater and other water mass indicators in the Arctic Ocean, J. Geophys. Res., 110, G02013, doi:10.1029/2005JG000031, 2005.

Dickson, A. G. and Millero, F. J.: A comparison of the equilibrium constants for the dissociation of carbonic acid in seawater media, Deep-Sea Res., 34, 1733-1743, 1987.

Dittmar, T. and Kattner, G.: The biogeochemistry of the river and shelf ecosystem of the Arctic Ocean: A review, Mar. Chem., 83, 103-120, 2003.

DOE: Handbook of Methods for the Analysis of the Various Parameters of the Carbon Dioxide System in Sea Water, Version 2, edited by: Dickson, A. G. and Goyet, C., 1994.

Dudarev, O., Semiletov, I., Botsul, A., and Charkin, A.: Modern sedimentation in the coastal cryolithozone of the Dmitry Laptev Strait/East-Siberian Sea, Russ. J. Pac. Geol., 22, 51-60, 2003 (translated into English).

Dudarev, O. V., Semiletov, I. P., and Charkin, A. N.: Particulate material composition in the Lena River-Laptev Sea system: scales of heterogeneities, Dokl. Earth Sci., 411, 1445-1451, 2006.

Feng, X., Vonk, J. E., van Dongen, B. E., Gustafsson, O., Semiletov, I. P., Dudarev, O. V., Wangh, Z., Montlucon, D. B., Wackeri, L., and Eglinton, T. I.: Differential mobilization of terrestrial carbon pools in Eurasian Arctic river basins, P. Natl. Acad. Sci. USA, 110, 14168-14173, doi:10.1073/pnas.1307031110, 2013.

Fichot, C. G., Kaiser, K., Hooker, S. B., Amon, R. M. W., Babin, M., Bélanger, S., Walker, S. A., and Benner, R.: Pan-Arctic distributions of continental runoff in the Arctic Ocean, Sci. Rep. 3, 1053, doi:10.1038/srep01053, 2013.

Freeman, C., Evans, C. D., Monteith, D. T., Reynolds, B., and Fenner, N.: Export of organic carbon from peat soils, Nature, 412, 785, doi:10.1038/35090628, 2001.

Goñi, M. A., Yunker, M. B., Macdonald, R. W., and Eglinton, T. I.: The supply and preservation of ancient and modern components of organic carbon in the Canadian Beaufort Shelf of the Arctic Ocean, Mar. Chem., 93, 53-73, 2005.

Gordeev, V. V., Martin, J. M., Sidorov, I. S., and Sidorova, M. V.: A reassessment of the Eurasian river input of water, sediment, major elements, and nutrients to the Arctic Ocean, Am. J. Sci., 296, 664-691, 1996.

Grigoriev, M. N.: Criomorphogenesis of the mouth area of the Lena River, Yakutsk, Institute of Permafrost Study of the Siberian Branch of the Russian Academy of Science, 1-176, 1993 (in Russian).

Grigoriev, M. N.: Cryomorphogenesis and Lithodynamics of the Coastal-shelf Zone of the Seas of Eastern Siberia. PhD thesis, Yakutsk Melnikov Permafrost Inst., 40 pp., 2008 (in Russian).

Grigoriev, M. N. and Kunitsky, V. V.: Destruction of the sea coastal ice-complex in Yakutia, in: Hydrometeorological and Biogeochemical Research in the Arctic, Proc. Arctic Regional Center, 2, edited by: Semiletov, I. P., Dal'nauka Press, Vladivostok, 109_ 116, 2000 (in Russian).

Grigoriev, M. N., Razumov, S. O., Kunitzkiy, V. V., and Spektor, V. B.: Dynamics of the Russian East Arctic Sea coast: Major factors, regularities and tendencies, Earth's Cryosphere, X, 7494, 2006 (in Russian).

Gruber, N., Friedlingstein, P., Field, C. B., Valentini, R., Heimann, M., Richey, C. B., Romero-Lankao, P., Schulze, D., and Chen, C.-T. A.: The vulnerability of the carbon cycle in the 21 st century: An assessment of carbon-climate-human interactions, in: 
The Global Carbon Cycle: Integrating Humans, Climate, and the Natural World, edited by: Field, C. B. and Raupach, M. R., Island Press, Washington, DC, 45-76, 2004.

Guo, L., Semiletov, I., Gustafsson, Ö., Ingri, J., Andersson, P., Dudarev, O., and White, D.: Characterization of Siberian Arctic coastal sediments: Implications for terrestrial organic carbon export, Global Biogeochem. Cy., 18, GB1036, doi:10.1029/2003GB002087, 2004.

Gustafsson, Ö., Haghseta, F., Chan, C., MacFarlane, J., and Gschwend, P. M.: Quantification of the dilute sedimentary soot phase: Implications for PAH speciation and bioavailability, Environ. Sci. Technol., 31, 203-209, 1997.

Gustafsson, Ö., van Dongen, B. E., Vonk, J. E., Dudarev, O. V., and Semiletov, I. P.: Widespread release of old carbon across the Siberian Arctic echoed by its large rivers, Biogeosciences, 8, 1737-1743, doi:10.5194/bg-8-1737-2011, 2011.

Haraldsson, C., Anderson, L. G., Hassellov, M., Hulth, S., and Olsson, K.: Rapid, high-precision potentiometric titration of alkalinity in ocean and sediment pore waters, Deep-Sea Res. Pt. I, 44, 2031-2044, 1997.

Heim, B., Abramova, E., Doerffer, R., Günther, F., Hölemann, J., Kraberg, A., Lantuit, H., Loginova, A., Martynov, F., Overduin, P. P., and Wegner, C.: Ocean Colour remote sensing in the Southern Laptev Sea: evaluation and applications, Biogeosciences Discuss., 10, 3849-3889, doi:10.5194/bgd-10-3849-2013, 2013.

Holemann, J., Kirillov, S., Klagge, T., Novikhin, A., Kassens, H., and Timokhov, L.: Near-bottom water warming in the Laptev Sea in response to atmospheric sea-ice conditions in 2007, Polar Res., 30, 6425-6440, 2011.

Holmes, R. M., Peterson, B. J., Zhulidov, A. V., Gordeev, V. V., Makkaveev, P. N., Stunzas, P. A., Kosmenko, L. S., Kohler, G. H., Shiklomanov, A. I.: Nutrient chemistry of the Ob' and Yenisey rivers, Siberia: results from June 2000 expedition and evaluation of long-term data sets, Mar. Chem., 75, 219-227, 2001.

Holmes, R. M., McClelland, J. W., Raymond, P. A., Franzer, B. B., Peterson, B. J., and Stieglitz, M.: Lability of DOC transported by Alaskan rivers to the Arctic Ocean, Geophys. Res. Lett., 35, L03402, doi:10.1029/2007GL032837, 2008.

IPCC: The Physical Science Basis, Contribution of Working Group I to the Fourth Assessment Report of the Intergovernmental Panel on Climate Change, edited by: Solomon, S., Qin, D., Manning, M., Chen, Z., Marquis, M., Avery, K. B., Tignor, M., and Miller, H. L., Cambridge University Press, Cambridge, UK and NY, NY, USA, Climate Change, 996 pp., 2007.

Jørgensen, N. O. G., Tranvik, L., Edling, H., Granéli, W., and Lindell, M.: Effects of sunlight on occurrence and bacterial turnover of specific carbon and nitrogen compounds in lake water, FEMS Microbiol. Ecol., 25, 217-227, 1998.

Karlsson, E. S., Charkin, A., Dudarev, O., Semiletov, I., Vonk, J. E., Sánchez-García, L., Andersson, A., and Gustafsson, Ö.: Carbon isotopes and lipid biomarker investigation of sources, transport and degradation of terrestrial organic matter in the Buor-Khaya Bay, SE Laptev Sea, Biogeosciences, 8, 1865-1879, doi:10.5194/bg-8-1865-2011, 2011.

Kassens, H., Bauch, H. A., Dmitrenko, J. A., Eicken, H., Hubberten, H. W., Melles, M., Thiede, J., and Timokhov, L. A.: Land-Ocean Systems in the Siberian Arctic: Dynamics and History, Springer, Berlin Heidelberg New York, 711 pp., 1999.
Kodina, L. A.: The carbon isotope composition of phytoplankton along the Ob-Kara Sea transect in August-September 1999, Rep. Polar Res., 393, 157-160, 2001.

Kodina, L. A.: Carbon isotope composition of phytoplankton in the Yenisei River-estuary-open sea system and the application of isotopic approach for evaluation of phytoplankton contribution to the Yenisei POC load, Ber. Polarforsch., 419, 143-149, 2002.

Lara, R. J., Rachold, V., Kattner, G., Hubberten, H.-W., Guggenbergen, G., Skoog, A., and Thomas, D. N.: Dissolved organic matter and nutrients in the Lena River, Siberian Arctic: Characteristics and distribution, Mar. Chem., 59, 301-309, 1998.

Lewis, E. and Wallace, D. W. R.: Program developed for $\mathrm{CO}_{2}$ system calculations, ORNL/CDIAC-105, Carbon Dioxide Information Analysis Center, Oak Ridge National Laboratory, US Department of Energy, Oak Ridge, Tennessee, 1998.

Macdonald, R. W., Anderson, L. G., Christensen, J. P., Miller, L. A., Semiletov, I. P., and Stein, R.: The Arctic Ocean: Budgets and fluxes, in: Carbon and Nutrient Fluxes in Continental Margins: A Global Synthesis, edited by: Liu, K.-K., Atkinson, L., Quinones, R., and Talaue-McManus, L., Springer, Berlin, 291-303, 2008.

Mantoura, R. F. C. and Woodward, E. M. S.: Conservative behavior of riverine dissolved organic-carbon in the Severn Estuary chemical and geochemical implications, Geochim. Cosmochim. Ac., 47, 1293-1309, 1983.

McGuire, A. D., Christensen, T. R., Hayes, D., Heroult, A., Euskirchen, E., Kimball, J. S., Koven, C., Lafleur, P., Miller, P. A., Oechel, W., Peylin, P., Williams, M., and Yi, Y.: An assessment of the carbon balance of Arctic tundra: comparisons among observations, process models, and atmospheric inversions, Biogeosciences, 9, 3185-3204, doi:10.5194/bg-9-3185-2012, 2012.

Mehrbach, C., Culberson, C. H., Hawley, J. E., and Pytkowicz, R. M.: Measurement of the apparent dissociation constants of carbonic acid in seawater at atmospheric pressure, Limnol. Oceanogr., 18, 897-907, 1973.

Nicolsky, D. and Shakhova, N.: Modeling sub-sea permafrost in the East-Siberian Arctic Shelf: the Dmitry Laptev Strait, Env. Res. Lett., 5, doi:10.1088/1748-9326/5/1/015006, 2010.

Nicolsky, D. J., Romanovsky, V. E., Romanovskii, N. N., Kholodov, A. L., Shakhova, N. E., and Semiletov, I. P.: Modeling sub-sea permafrost in the East Siberian Arctic Shelf: The Laptev Sea region, J. Geophys. Res., 117, F03028, doi:10.1029/2012JF002358, 2012.

Nikiforov, E. G. and Shpaikher, A. O.: Features of the formation of hydrological regime large-scale variations in the Arctic Ocean, Hydrometeoizdat, Leningrad, 269 pp., 1980 (in Russian).

Pavlova, G. Yu., Tishchenko, P. Ya., Volkova, T. I., Dickson, A., and Wallmann, K.: Intercalibration of Bruevich's method to determine the total alkalinity in seawater, Oceanology, 48, 460-465, 2008.

Petelin, V. P.: New method of water-mechanical analysis of marine bottom sediment, Oceanology, 1, 143-148, 1961 (in Russian).

Pipko, I. I., Semiletov, I. P., and Pugach, S. P.: The carbonate system of the East Siberian Sea waters, Dokl. Earth Sci., 402, 624-627, 2005.

Pipko, I., Semiletov, I. P., Tishchenko, P. Ya., Pugach, S. P., and Savel'eva, N. I.: Variability of the carbonate system parameters in the coast-shelf zone of the East Siberian Sea during the autumn season, Oceanology, 48, 1, 54-67, 2008. 
Pipko, I. I., Pugach, S. P., Dudarev, O. V., Charkin, A. N., and Semiletov, I. P.: Carbonate parameters of the Lena River: Characteristics and distribution, Geochem. Int., 48, 1131-1137, 2010.

Pipko, I. I., Semiletov, I. P., Pugach, S. P., Wåhlström, I., and Anderson, L. G.: Interannual variability of air-sea $\mathrm{CO}_{2}$ fluxes and carbon system in the East Siberian Sea, Biogeosciences, 8, 19872007, doi:10.5194/bg-8-1987-2011, 2011a.

Pipko, I. I., Pugach, S. P., Semiletov, I. P., and Salyuk, A. N.: Carbonate Characteristics of Waters of the Arctic Ocean Continental Slope, Dokl. Earth Sci., 438, 858-863, 2011b.

Porcelli, D., Andersson, P., Baskaran, M., Frank, M., Björk, G., and Semiletov, I.: The distribution of neodymium isotopes in Arctic Ocean basins, Geochim. Cosmochim. Ac., 73, 2645-2659, 2009.

Proshutinsky, A. Y. and Johnson, M. A.: Two circulation regimes of the wind-driven Arctic Ocean, J. Geophys. Res., 102, 1249312514, 1997.

Proshutinsky, A., Timmermans, M.-L., Ashik, I., BeszczynskaMoeller, A., Carmack, E., Frolov, I., Ingvaldsen, R., Itoh, M., Kikuchi, T., Krishfield, R., McLaughlin, F., Loeng, H., Nishino, S., Puickart, R., Rabe, B., Rudels, B., Semiletov, I., Schauer, U., Shakhova, N., Shimada, K., Sokolov, V., Steele, M., Toole, J., Weingarther, T., Williams, W., Woodgate, R., Yamamoto-Kawai, M., and Zimmermann, S.: The Arctic Ocean, in: State of the Climate in 2011, B. Am. Meteorol. Soci., 93, S142-S145, 2012.

Pugach, S. P. and Pipko, I. I.: Dynamic of colored dissolved organic matter on the East-Siberian Sea shelf, Dokl. Earth Sci., 448, 153156, 2013.

Rachold, V., Grigoriev, M. N., Are, F. E., Solomon, S., Reimnnitz, E., Kassens, H., and Antonow, M.: Coastal erosion vs. riverine sediment discharge in the Arctic shelf seas, Int. J. Earth Sci., 89, 450-460, 2000.

Rachold, V., Eicken, H., Gordeev, V., Grigoriev, M., Hubberten, H., Lisitzin, A., Shevchenko, V., and Schirmeister, L.: Modern terrigenous organic carbon input to the Arctic Ocean, in: edited by: The Organic Carbon Cycle in the Arctic Ocean, Stein, R. and Macdonald, R. W., Springer-Verlag, Berlin, Heidelberg, New York, 512 pp., 2004.

Sánchez-Garcia, L., Alling, V., Pugach, S., Vonk, J., van Dongen, B., Humborg, C., Dudarev, O., Semiletov, I., and Gustafsson, Ö.: Inventories and behavior of particulate organic carbon in the Laptev and East Siberian seas, Global Biogeochem. Cy., 25, GB2007, doi:10.1029/2010GB003862, 2011.

Savelieva, N. I., Semiletov, I. P., Vasilevskaya, L. N., and Pugach, S. P.: A climate shift in seasonal values of meteorological and hydrological parameters for Northeastern Asia, Prog. Oceanogr., 47, 279-297, 2000.

Semiletov, I. P.: Ancient ice air content of the Vostok Ice Core, in: Biogeochemistry of Trace Gases, edited by: Oremland, S., Chapman and Hall Inc., New York, 46-59, 1993.

Semiletov, I. P.: On aquatic sources and sinks of $\mathrm{CO}_{2}$ and $\mathrm{CH}_{4}$ in the polar regions, J. Atmos. Sci., 56, 286-306, 1999a.

Semiletov, I. P.: The failure of coastal frozen rock as an important factor in the biogeochemistry of the arctic shelf water, Dokl. Earth Sci., 369(8), 1140-1143, 1999b.

Semiletov, I. P. and Pipko, I. I.: Sinks and sources of carbon dioxide in the Arctic Ocean: Results of direct instrumental measurements, Dokl. Earth Sci., 414, 642-645, 2007.

Semiletov, I. P., Pipko, I. I., Pivovarov, N. Ya., Popov, V. V., Zimov, S. A., Voropaev, Yu. V., and Daviodov, S. P.: Atmospheric carbon emission from north Asian lakes: A factor of global significance, Atmos. Environ., 30, 1657-1671, 1996a.

Semiletov, I. P., Pivovarov, N. Ya., Pipko, I. I., Gukov, A.Yu., Volkova, T. I., Sharp, J. P., Shcherbakov, Yu. S., and Fedorov, K. P.: Dynamics of dissolved $\mathrm{CH}_{4}$ and $\mathrm{CO}_{2}$ in the Lena River Delta and Laptev Sea, Transactions (Doklady) of the Russian Academy of Sciences, 350, 401-404, 1996b (translated into English).

Semiletov, I. P., Savelieva, N. I., Weller, G. E., Pipko, I. I., Pugach, S. P., Gukov, A. Yu., and Vasilevskaya, L. N.: The dispersion of Siberian river flows into coastal waters: Meteorological, hydrological and hydrochemical aspects, in: The Freshwater Budget of the Arctic Ocean, NATO Meeting/NATO ASI Series, edited by: Lewis, E. L., Kluwer Academic Publishers, Dordrecht, 323-367, 2000.

Semiletov, I. P., Makshtas, A., Akasofu, S.-I., and Andreas, E.: Atmospheric $\mathrm{CO}_{2}$ balance: The role of Arctic sea ice, Geophys. Res. Lett., 31, L05121, doi:10.1029/2003GL017996, 2004.

Semiletov, I., Dudarev, O., Luchin, V., Charkin, A., Shin, K., and Tanaka, N.: The East-Siberian Sea as a transition zone between the Pacific origin water and local shelf water, Geophys. Res. Lett., 32, L10614, doi:10.1029/2005GL022490, 2005.

Semiletov, I. P., Pipko, I. I., Repina, I., and Shakhova, N. E.: Carbonate chemistry dynamics and carbon dioxide fluxes across the atmosphere-ice-water interfaces in the Arctic Ocean: Pacific sector of the Arctic, J. Marine Syst., 66, 204-226, 2007.

Semiletov, I. P., Pipko, I. I., Shakhova, N. E., Dudarev, O. V., Pugach, S. P., Charkin, A. N., McRoy, C. P., Kosmach, D., and Gustafsson, Ö.: Carbon transport by the Lena River from its headwaters to the Arctic Ocean, with emphasis on fluvial input of terrestrial particulate organic carbon vs. carbon transport by coastal erosion, Biogeosciences, 8, 2407-2426, doi:10.5194/bg8-2407-2011, 2011.

Semiletov, I. P., Shakhova, N. E., Sergienko, V. I., Pipko, I. I., and Dudarev, O. V.: On carbon transport and fate in the East Siberian Arctic land-shelf-atmosphere system, Environ. Res. Lett., 7, 015201, doi:10.1088/1748-9326/7/1/015201, 2012.

Shakhova, N. and Semiletov, I.: Methane release and coastal environment in the East Siberian Arctic shelf, J. Mar. Syst., 66 , 227-243, 2007.

Shakhova, N. and Semiletov, I.: Trace gas emissions from sub-sea permafrost. In: Climate Change and the Cryosphere: Snow, Water, Ice and Permafrost in the Arctic (SWIPA): An Arctic Council "Cryosphere Project" in Cooperation with IASC, CliC and IPY, A report of the Arctic Monitoring and Assessment Program (AMAP), Oslo, Norway, 97-104, 2012.

Shakhova, N. E., Nicolsky, D., and Semiletov, I. P.: Current state of subsea permafrost on the East Siberian Shelf: Tests of modeling results based on field observations, Dokl. Earth Sci., 429, 15181521, 2009a.

Shakhova, N. E., Sergienko, V. I., and Semiletov, I. P.: Modern state of the role of the East Siberian Shelf in the methane cycle, Her. Russ. Acad. Sci., 79, 507-518, 2009b (translated into English by Springer).

Shakhova, N., Semiletov, I., Leifer, I., Rekant, P., Salyuk, A., and Kosmach, D.: Geochemical and geophysical evidence of methane release from the inner East Siberian Shelf, J. Geophys. Res., 115, C08007, doi:10.1029/2009JC005602, 2010a.

Shakhova, N., Semiletov, I., Salyuk, A., Yusupov, V., Kosmach, D., and Gustafsson, Ö.: Extensive methane venting to the atmo- 
sphere from sediments of the East Siberian Arctic Shelf, Science, 327, 1246-1250, 2010b.

Shakhova, N., Semiletov I., and Gustafsson, Ö.: Methane from the East Siberian Arctic Shelf/Response, Science, 329, 1147-1148, 2010c.

Shepard, F. P.: Nomenclature based on sand-silt-clay ratios, J. Sediment. Petrol., 24, 151-158, 1954.

Soloviev, V. A., Ginzburg, G. D., Telepnev, E. B., and Mihalyuk, Yu. N.: Cryothermia and natural gas hydrates within the Arctic Ocean, Sevmorgeologiya, Leningrad, 150 pp., 1987 (in Russian).

Sondergaard, M. and Middelboe, M.: A cross-system analysis of labile dissolved organic carbon, Mar. Ecol.-Prog. Ser., 118, 283294, 1995.

Sorokin, Yu. A. and Sorokin, P. Yu.: Plankton and primary production in the Lena River estuary and in the South-eastern Laptev Sea, Estuar. Coast. Shelf Sci., 43, 399-418, 1996.

Stein, R. and Macdonald, R. W.: The Organic Carbon Cycle in the Arctic Ocean, Springer-Verlag, Berlin, 417 pp., 2004.

Tarnocai, C., Canadell, J. G., Schuur, E. A. G., Kuhry, P., Mazhitova, G., and Zimov, S.: Soil organic carbon pools in the northern circumpolar permafrost region, Global Biogeochem. Cy., 23, GB2023, doi:10.1029/2008GB003327, 2009.

van Dongen, B. E., Semiletov, I. P., Weijers, J. W. H., and Gustafsson, Ö.: Contrasting lipid biomarker composition of terrestrial organic matter exported from across the Eurasian Arctic by the five Great Russian Arctic Rivers, Global Biogeochem. Cy., 22, GB1011, doi:10.1029/2007GB002974, 2008.

Vonk, J. E., Sánchez-García, L., Semiletov, I., Dudarev, O., Eglinton, T., Andersson, A., and Gustafsson, Ö.: Molecular and radiocarbon constraints on sources and degradation of terrestrial organic carbon along the Kolyma paleoriver transect, East Siberian Sea, Biogeosciences, 7, 3153-3166, doi:10.5194/bg-73153-2010, 2010.
Vonk, J. E., Sánchez-García, L., van Dongen, B. E., Alling, V., Kosmach, D., Charkin, A., Semiletov, I. P., Dudarev, O. V., Shakhova, N., Roos, P., Eglinton, T. I., Andersson, A. and Gustafsson, Ö.: Activation of old carbon by erosion of coastal and subsea permafrost in Arctic Siberia, Nature, 489, 137-140, 2012.

Walsh, J. J., McRoy, C. P., Coachman, L. K., Goering, J. J., Nihoul, J. J., Whitledge, T. E., Blackburn, T. H., Parker, P. L., Wirick, C. D., Shuert, P. G., Grebmeier, J. M., Springer, A. M., Tripp, R. D., Hansell, D. A., Djenidi, S., Deleersnijder, E., Henriksen, K., Lund, B. A., Andersen, P., Muller-Karger, F. E., and Dean, K.: Carbon and nitrogen cycling within the Bering/Chukchi Seas: Source regions for organic matter effecting AOU demands of the Arctic Ocean, Prog. Oceanogr., 22, 277-359, 1989.

Wanninkhof, R.: Relationship between wind speed and gas exchange over the ocean, J. Geophys. Res., 97, 7373-7382, 1992.

Wanninkhof, R. and McGillis, W. R.: A cubic relationship between air-sea $\mathrm{CO}_{2}$ exchange and wind speed, Geophys. Res. Lett., 26, 1889-1892, 1999.

Weiss, R. F.: The solubility of nitrogen, oxygen and argon in water and seawater, Deep-Sea Res., 17, 721-735, 1970.

Weiss, R. F.: Determination of gas carbon dioxide and methane by duel catalyst flame ionization chromatography and nitrous oxide by electron capture chromatography, J. Chromatogr. Sci., 19, 611-616, 1981.

Wiegner, T. N. and Seitzinger, S. P.: Photochemical and microbial degradation of external dissolved organic matter inputs to rivers, Aquat. Microb. Ecol., 24, 27-40, 2001.

Zimov, S. A., Semiletov, I. P., Daviodov, S. P., Voropaev, Yu. V., Prosyannikov, S. F., Wong, C. S., and Chan, Y.-H.: Wintertime $\mathrm{CO}_{2}$ emission from soils of Northeastern Siberia, Arctic, 46, 197-204, 1993.

Zimov, S. A., Voropaev, Yu. V., Semiletov, I. P., Daviodov, S. P., Chapin, F. S., and Trumbore, S.: North Siberian lakes: a methane source fueled by Pleistocene carbon, Science, 277, 800-802, 1997. 